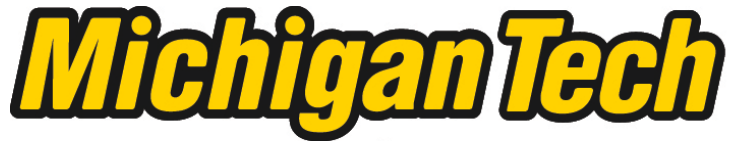 \\ Michigan Technological University Create the Future Digital Commons @ Michigan Tech
}

Dissertations, Master's Theses and Master's Reports - Open

Dissertations, Master's Theses and Master's

Reports

2012

\section{Biofilm responses to salmon carcass analog addition in central Idaho streams}

Jonathan D. Ebel

Michigan Technological University

Follow this and additional works at: https://digitalcommons.mtu.edu/etds

Part of the Biology Commons

Copyright 2012 Jonathan D. Ebel

\section{Recommended Citation}

Ebel, Jonathan D., "Biofilm responses to salmon carcass analog addition in central Idaho streams", Master's Thesis, Michigan Technological University, 2012.

https://doi.org/10.37099/mtu.dc.etds/186

Follow this and additional works at: https://digitalcommons.mtu.edu/etds

Part of the Biology Commons 


\title{
BIOFILM RESPONSES TO SALMON CARCASS ANALOG ADDITION IN CENTRAL IDAHO STREAMS
}

\author{
By: \\ Jonathan D. Ebel \\ Submitted in partial fulfillment of the requirements for the degree of \\ MASTER OF SCIENCE \\ (Biological Sciences)
}

MICHIGAN TECHNOLOGICAL UNIVERSITY

2012

(C) 2012 Jonathan D. Ebel 
This thesis, "Biofilm Responses to Salmon Carcass Analog Addition in Central Idaho Streams," is hereby approved in partial fulfillment of the requirements for the Degree of MASTER OF SCIENCE IN BIOLOGICAL SCIENCES.

Department of Biological Sciences

\section{Signatures:}

Thesis Advisor

Dr. Amy M. Marcarelli

Committee Member

Dr. Casey Huckins

Committee Member

Dr. Erik Lilleskov

Department Chair

Dr. Chandrashekhar P. Joshi

Date 
The migration of juvenile salmon from their natal streams to the ocean constitutes an enormous challenge; they must swim through hundreds of miles of slack water, escape the jaws of a plethora of beasts trying to eat them, and survive eight vertical drops through spinning hydroelectric turbines. It's amazing that any of the young salmon ever make it to the ocean. Each salmon must have a friend like Beth. 


\section{Table of Contents}

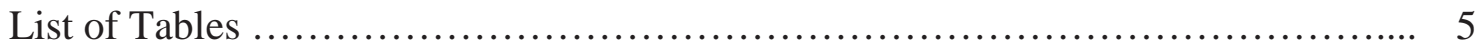

List of Figures.......................................................... 6

Acknowledgments........................................................... 7

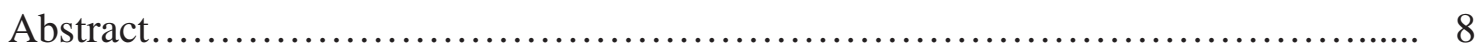

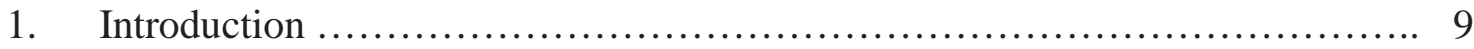

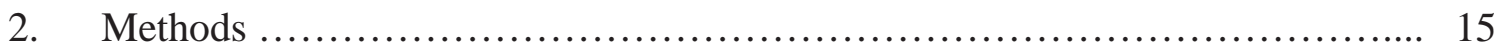

2.1. Study area and design......................................... 15

2.2. Physical characteristics......................................... 19

2.3. Biofilm standing crop......................................... 21

2.4. Nutrient limitation............................................... 23

2.5. Metabolism....................................................... 24

2.5.1. Whole-stream metabolism.............................. 24

2.5.2. Benthic metabolism...................................... 27

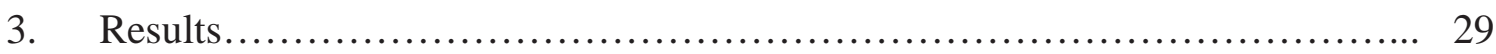

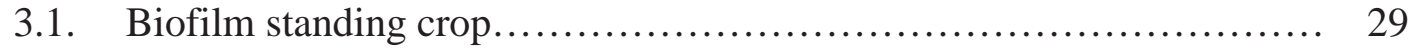

3.2. Nutrient limitation.............................................. 32

3.3. Metabolism..................................................... 38

3.3.1. Whole-stream metabolism.............................. 38

3.3.2. Benthic metabolism..................................... 43

4. Discussion........................................................ 44

4.1. Experimental design.......................................... 45

4.2. Biofilm response to salmon nutrients............................ 47

4.3. Constraints on biofilm standing crop............................ 52

4.4. Alternative fates of salmon carcass analog........................ 55

4.5. Future of the biofilm pathway................................ 57

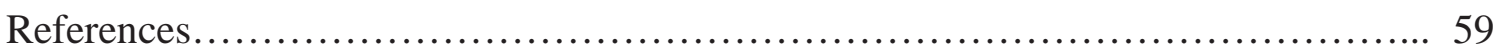




\section{List of Figures}

Figure 2.1 Maximum daily discharge of the mainstem Salmon River below Yankee Fork confluence................................... 17

Figure $2.2 \quad$ Location of study streams................................. 18

Figure $2.3 \quad$ Schematic of study design................................. 18

Figure 3.1 Chlorophyll $a$ and AFDM on natural substrates collected before

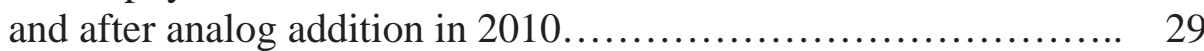

Figure 3.2 Chlorophyll $a$ and AFDM on natural substrates collected before

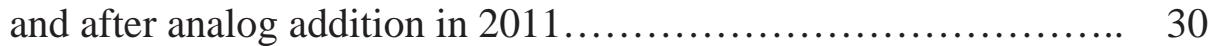

Figure 3.3 Relationship of chlorophyll $a$ concentration on rocks collected after analog addition in 2011 with canopy cover and discharge......

Figure 3.4 Standing crop of chlorophyll $a$ on nutrient diffusing substrates deployed before and after analog addition..................... 36

Figure 3.5 Standing crop of AFDM on nutrient diffusing substrates deployed before and after analog addition.................................

Figure 3.6 Time series of gross primary productivity, ecosystem respiration, net ecosystem production in Basin Creek and Cape Horn Creek.....

Figure 3.7 Figure 3.6. Respiration, net primary production, and gross primary productivity of benthic biofilms 


\section{List of Tables}

Table 2.1 Stream characteristics at study segments ........................ 20

Table 2.2 Power analysis for chlorophyll $a$ responses to analog additions in tributary streams of the Salmon River in summer 2010 and 2011

Table 2.3 Power analysis for AFDM responses to analog additions in tributary streams of the Salmon River in summer 2010 and 2011

Table 2.4 Empirical equations used to calculate the reaeration coefficients

Table 3.1 Two-way ANOVA results for chlorophyll $a$ and AFDM on natural substrates

Table 3.2 Results of three-way ANOVA on log-transformed chlorophyll $a$ concentrations on nutrient diffusing substrates

Table 3.3 Results of chlorophyll $a$ nutrient limitation from nutrient diffusing substrates...

Table 3.4 Results of AFDM nutrient limitation from nutrient diffusing substrates.. 35

Table 3.5 Reaeration coefficients of control and treatment segments of Cape Horn Creek and Basin Creek during September 2011.....................

Table 3.6 Median daily GPP, ER, NEP, and P : R in control and treatment segments of high analog and low analog streams...

Table 3.7 Results of one-tailed $t$-tests on NPP (light chambers) and R (dark chambers) 


\section{Acknowledgments}

This research required the assistance of many people. I greatly appreciate their thoughts, time, and effort.

My advisor, Dr. Amy Marcarelli, for her help with everything in this document.

Dr. Casey Huckins and Dr. Erik Lilleskov (committee members) for their insights. Andre Kohler for his insights, enthusiasm, help with logistics, and being awesome.

Dr. Colden Baxter and his entire lab at Idaho State University for the use of their equipment and periodically adopting me as their own.

Nicole Matthias, Jennifer Cornell, Jamey Anderson, Dan Drake, Jeffery Kiiskila, Ray Saliga, Tim Veverica, Phillip Mercier, and Heather Salmon for their assistance with laboratory analyses.

Matt Schenk, David Richardson, Tyron Bronco, Payton Sequints, Ryan Bellmore, Hannah Harris, and Kelsey Flandro for their assistance in the field.

Bonneville Power Administration, Shoshone-Bannock Tribes, Michigan Technological University, Ecosystem Science Center and the Center for Water and Society for financial support. 


\begin{abstract}
Pacific salmon populations have declined due to human activity in the Pacific Northwest, resulting in decreased delivery of marine-derived nutrients to streams. Managers use artificial nutrient additions to increase juvenile salmon growth and survival and assume that added nutrients stimulate biofilm production, which propagates up the food web to juvenile salmon. We assessed biofilm responses (standing crop, nutrient limitation, and metabolism) to experimental additions of salmon carcass analog in tributaries of the Salmon River, Idaho in 2010 and 2011. Biofilm standing crop and nutrient limitation did not respond to analog, but primary productivity and respiration increased in the subset of streams where they were measured. Discrepancies between biofilm productivity and standing crop may occur if standing crop is constrained by physical and biological factors. Thus, conclusions about biofilm response to analog should not be based on standing crop alone and mitigation research may benefit from nutrient budgets of entire watersheds.
\end{abstract}




\section{INTRODUCTION}

The movement of organisms, nutrients, and energy that connect ecosystems (i.e., resource subsidies) can substantially influence the biological and physiochemical dynamics of the receiving habitats (Polis et al. 1997). Stream ecologists have demonstrated that inputs of terrestrial organic matter (e.g., leaves) and prey (e.g., invertebrates) can dominate ecosystem energy budgets (Fisher and Likens 1973; Webster and Meyer 1997), control nutrient cycling rates (Valett et al. 2008), and alter intra- and inter-trophic level relationships (Nakano et al. 1999; Moore et al. 2004). More recently, ecologists have recognized the importance of interactions between the quantity and quality of resource subsidies to food webs and ecosystem processes (Marcarelli et al. 2011). Subsidies can enter streams as living or dead biomass. Nutrients and carbon are released as dissolved or particulate organic matter through a combination of interacting physical, chemical, and biological forces that drive decomposition rates (Suberkropp et al. 2010; Fenoglio et al. 2010). Dissolved nutrients and fine particulates are then available for capture by biofilms, which are corsortia of algal, bacterial, and fungal species that coinhabit the surface of cobbles, sediments, wood, and plants in the stream channel. Biofilms are responsible for a significant proportion of primary production, carbon metabolism and nutrient cycling in streams.

Pacific salmon (Oncorhynchus spp.) are widely recognized as an important resource subsidy that regulates the ecological dynamics of the rivers in which they spawn. Salmon transport carbon and nutrients from marine ecosystems to their natal freshwater streams. The carbon and nutrients are released as labile compounds through 
excretion, post-spawn carcass decomposition, and the direct consumption of tissue by other organisms (Chaloner et al. 2002). In regions with large salmon runs, organic material from dead salmon propogates through trophic levels of both aquatic and terrestrial communities (Kline et al. 1990; Bilby et al. 1996; Helfield and Naiman 2001; Hicks et al. 2005). In aquatic systems, salmon are also hypothesized to stimulate food webs via bottom up processes by alleviating algal nutrient limitation and increasing primary productivity (Juday et al. 1932; Nelson and Edmondson 1955). In turn, higher primary productivity increases invertebrate consumer production. Subsequently, higher invertebrate abundances should translate into increased growth and survival of juvenile salmon. In support of this hypothesis, studies have shown that spawning salmon and carcasses increase stream water nutrient concentrations (Mitchell and Lamberti 2005; Chaloner et al. 2007), eliminate biofilm nutrient limitation (Ruegg et al. 2011; Tiegs et al. 2011), and can increase biofilm and macroinvertebrate biomass (Wipfli et al. 1998; Wipfli et al. 1999).

In addition to bottom-up food-web stimulation, redd or nest digging behavior of spawning salmon is a disturbance mechanism, which may counteract the stimulatory effects of increased nutrient supply by dislodging benthic biofilms and macroinvertebrates (Peterson and Foote 2000; Moore and Schindler 2008; Tiegs et al. 2009; Holtgrieve and Schindler 2011). Generalized conclusions about the role of salmon as a consistent resource subsidy remain elusive (Janetski et al. 2009). Most likely, the diversity of physical and behavioral characteristics among and within salmon species across their historic ranges (i.e., body size, spawner density, timing of spawn) interacts with spatial and temporal variability in physical habitat characteristics to determine how 
ecosystem processes are influenced by spawning salmon (Ruegg et al. 2012). The effect of salmon on ecosystems and the salmon themselves are highly diverse (Schindler et al. 2010) and it is clear that stream ecosystems are as much a product of their salmon as the salmon are a product of their natal streams.

Over the past century, human activity has negatively affected Pacific salmon populations throughout much of their historic range with the steepest declines occurring in the contiguous United States (Nehlsen et al. 1991). Salmon populations in the Columbia River Basin are 5-7\% of historical levels because of hydroelectric dams, hatcheries, habitat destruction, and over-harvest (Lichatowich 1999; Gresh et al. 2000; Thomas et al. 2003). In many watersheds, the decline or extirpation of Pacific salmon has consequences for entire stream food webs. Streams with depressed salmon populations risk further salmon decline in a negative feedback pattern where nutrient limitation of algae and microbes limits juvenile salmon growth rates, in turn, decreasing their survival during and after out-migration (Larkin and Slaney 1997). Traditionally, salmon restoration initiatives have focused on hatchery supplementation and the maintenance, restoration, or creation of physical habitat for salmon spawning and rearing. Recently, researchers and managers have shifted their focus to the importance of spawning and dead salmon to production within stream food webs (Kiffney and Roni 2007; Wipfli and Baxter 2010), which ultimately has consequences for juvenile salmon and trout survival.

The use of artificial nutrient enrichment to bolster salmon populations was first tested in the 1950's as a way to stabilize commercial harvests. Inorganic fertilizer additions to sockeye salmon rearing lakes resulted in higher primary production and phytoplankton biomass, but failed to stimulate production in higher trophic levels 
(Nelson and Edmondson 1955). Whole-lake enrichments for stock enhancement were discontinued, but the practice was introduced as a tool for salmon conservation in the 1970’s in British Columbia, 1980's in Alaska, and mid 1990's in central Idaho (Hyatt et al. 2004). These later studies found that nitrogen and phosphorus additions translated into greater sockeye smolt weights and egg to smolt survival rates. Artificial nutrient enrichment of streams began in earnest in the mid-1990's, and tend to use organic rather than inorganic nutrients (Compton et al. 2006). Currently, salmon nutrient additions to streams are popular with state and tribal fisheries agencies in the Pacific Northwest as a salmon conservation and restoration tool commonly referred to as salmon nutrient mitigation (e.g., ODFW 2009; Kohler et al. 2012). Yet, the way nutrient subsidies enter the stream food web may limit the success of mitigation efforts.

Salmon nutrient mitigation research and application is dominated by the bottomup hypothesis and has focused on biofilms as the primary vector by which salmon nutrients are transferred into the food web. The bottom-up hypothesis assumes that algae are nutrient limited, and that algae have the capacity to respond to salmon nutrient addition. Primary producers are often limited by nitrogen or phosphorus or co-limited by both $\mathrm{N}$ and $\mathrm{P}$ (Harpole et al. 2011). Stream biofilm autotrophs are no exception (Tank and Dodds 2003; Sanderson et al. 2009), and nutrient limited algae tend to respond positively to nutrient additions. Secondary production by heterotrophic microbes may also be an important pathway for salmon nutrients into the foodweb; however, nutrient mitigation research has largely ignored responses of biofilm heterotrophs. Biofilm heterotrophs can be limited by algal carbon (e.g. Haack et al. 1988; Scott et al. 2008) and respond positively to additions of labile dissolved organic matter (Cooney and Simon 
2009; Van Horn et al. 2011). Additionally, inorganic nutrient enrichment can increase food quality for detritus-feeding macroinvertebrates by decreasing the $\mathrm{C}: \mathrm{N}$ ratio of fungi and bacteria (Cross et al. 2006). Yet, salmon nutrient enrichment does not consistently yield positive responses in either autotrophic or heterotrophic microbial standing crop (Janetski et al. 2009). The lack of consistent biofilm standing crop responses is likely due to spatial and temporal variability in physical and biological factors that constrain biomass accrual such as light (Hill et al. 1995), grazing (Rosemond 1993), and interactions between disturbance and biofilm development (Stoodley et al. 1999; Romani and Sabater 2001; Romani et al. 2004; Augspurger and Kusel 2010).

The objective of our study was to assess changes in biofilm nutrient limitation, standing crop, and metabolism following the addition of salmon carcass analog to tributaries of the Salmon River, Idaho. Salmon carcass analog is made of dried, pasteurized, and pelletized marine fishmeal (Pearsons et al. 2007) and may be a viable source of marine-derived carbon and nutrients to streams with depressed or extirpated salmon populations (Wipfli et al. 2004; Kohler et al. 2012). To date, most salmon-food web studies have used biofilm standing crop (i.e., chlorophyll $a$ and AFDM) or stable isotopes to determine the incorporation of salmon nutrients into biofilms including previous research in tributaries of the Salmon River (Kohler et al. 2008; Kohler and Taki 2010). We measured biofilm standing crop, biofilm nutrient limitation, benthic metabolism, and whole-stream metabolism in upstream and downstream segments of streams that received different analog loads. Metabolism is a measure of the primary production and respiration, which is dominated by autotrophic and heterotrophic microbial metabolic activity and integrates the processes governing organic matter 
dynamics and nutrient cycling (Tank et al. 2010). We predicted that (i) biofilm algal and heterotroph standing crop would be higher in stream segments that received analog addition than in segments without analog; (ii) biofilms would be predominantly nitrogen limited in the absence of analog and analog addition would alleviate or change nutrient limitation; (iii) analog addition would increase autotrophic and heterotrophic metabolic activity. 


\section{METHODS}

\subsection{Study area and design:}

From its headwaters in the Sawtooth and Salmon mountain ranges, the Salmon River flows north through the mountainous region of central Idaho before turning west to its confluence with the Snake River, a major tributary of the Columbia River. Peak stream discharge occurs during high elevation snow-melt between mid-June and early July and baseflow conditions typically persist from mid-July through the winter (Figure 2.1). Our study region is underlain by the Idaho Batholith geologic formation with Cretaceous granite and quartz diorite being the dominant rock types (Omernik 1987). Riparian vegetation is dominated by willow (Salix sp.) whereas upland areas consist mostly of lodgepole pine (Pinus contorum). As a result of watershed and regional characteristics, the study streams receive little geologic or vegetative nutrient inputs, and have low rates of atmospheric nitrogen deposition $\left(242 \mathrm{~kg} \mathrm{~N} \mathrm{~km}^{-2}\right.$ year $^{-1}$; National Atmospheric Deposition Program 2010, site ID03). Biofilms in nearby streams are nitrogen limited or co-limited by nitrogen and phosphorous (Marcarelli and Wurtsbaugh 2007; Sanderson et al. 2009). Streams in the upper Salmon River region are relatively undisturbed by human land-use practices other than scattered mines and dispersed livestock grazing. Natural disturbances include mountain pine beetle infestations (Logan and Powell 2001) and stand-removing wildfires in upland lodgepole pine forests (Malison and Baxter 2010). Watersheds are largely under federal ownership, draining areas of the Sawtooth Wilderness, Sawtooth National Recreation Area and the SalmonChallis National Forest. 
To evaluate the effect of analog addition on biofilms, we compared adjacent upstream control and downstream treatment segments in six streams during 2010 and 2011 (Figure 2.3). Segments were approximately $3 \mathrm{~km}$ in length. Biofilm standing crop sampling followed a Before-After-Control-Impact (BACI) design and a Control-Impact design was used to assess changes in biofilm nutrient limitation and metabolism. Study streams were $3^{\text {rd }}-4^{\text {th }}$ order with baseflow discharges between $0.04-0.97 \mathrm{~m}^{3} \mathrm{~s}^{-1}$ (Table 2.1). We separated the streams into two groups by geographic region: Elk Creek, Basin Creek and Cape Horn Creek near Stanley, ID and Panther Creek, Musgrove Creek and Moyer Creek north-west of Challis, ID (Figure 2.2). All of these streams likely supported healthy runs of Chinook salmon in the past, yet returning adults are rare in five of the study streams (Table 2.1). Cape Horn Creek, which drains into the Middle Fork of the Salmon River, is the only study stream with a sizeable run of Chinook salmon relative to the other study streams, albeit still small relative to historical levels (see Evermann 1896).

We experimentally added three different salmon carcass analog loads to treatment segments: No analog, $30 \mathrm{~g} / \mathrm{m}^{2}$ (low analog), or $150 \mathrm{~g} / \mathrm{m}^{2}$ (high analog) of bank-full channel area. Low analog density was based on target levels suggested by Wipfli et al. (2003) for comparison with earlier salmon carcass analog additions in the Pacific Northwest (see Kohler et al. 2012), whereas the high analog density was based on salmon escapement levels described by Bilby et al. (2001). The location and length of segments was decided based on the accessibility of the treatment segment and the proximity of the downstream edge of the study site to junctions with major tributaries. Analog addition 
occurred in the middle of August 2010 and 2011 to mimic the historical annual peak in Chinook spawning.

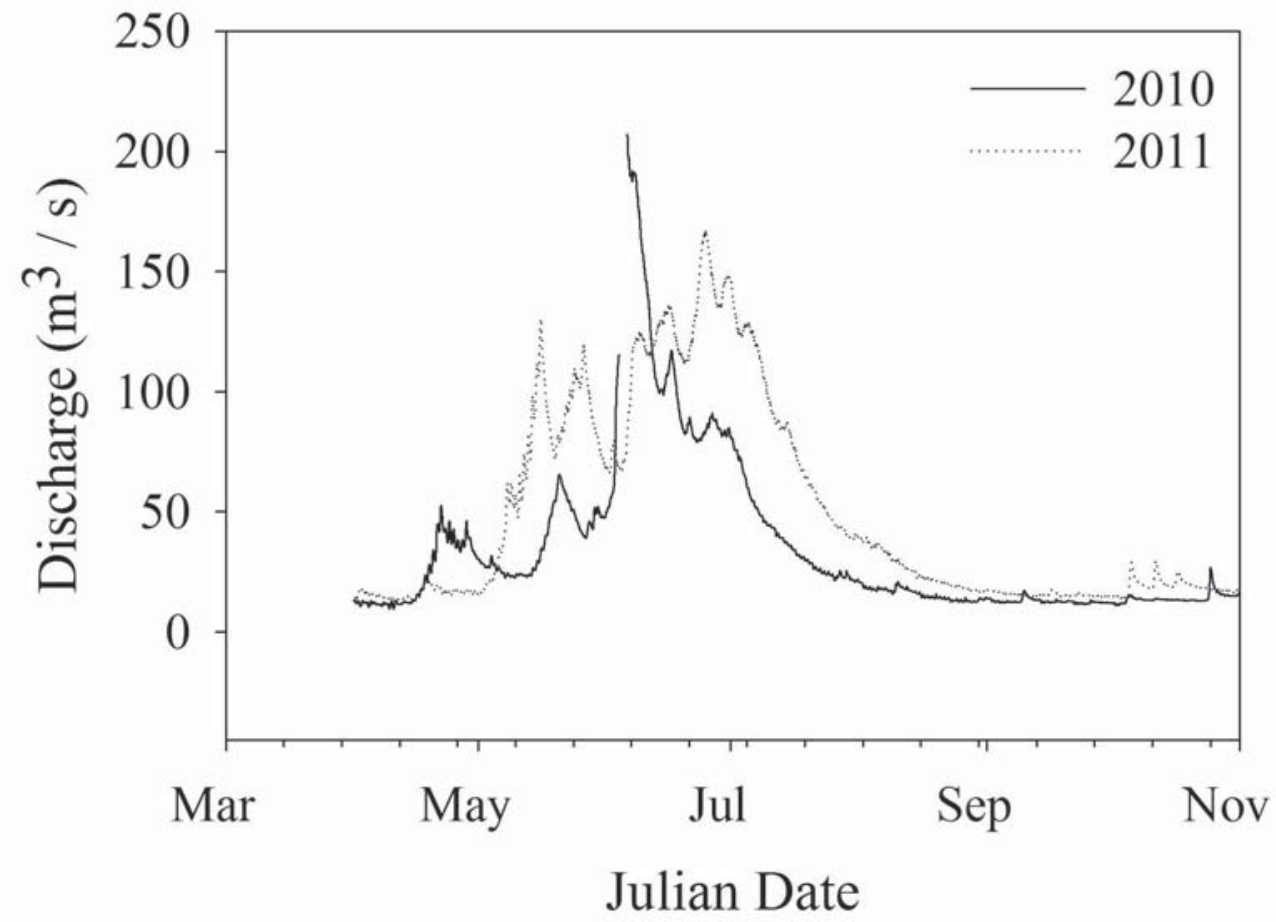

Figure 2.1 Maximum daily discharge of measured at the USGS discharge gauge on the mainstem Salmon River below Yankee Fork confluence (USGS \#13296500) beginning prior to spring snowmelt and ending at the end of the study period during 2010 and 2011. 


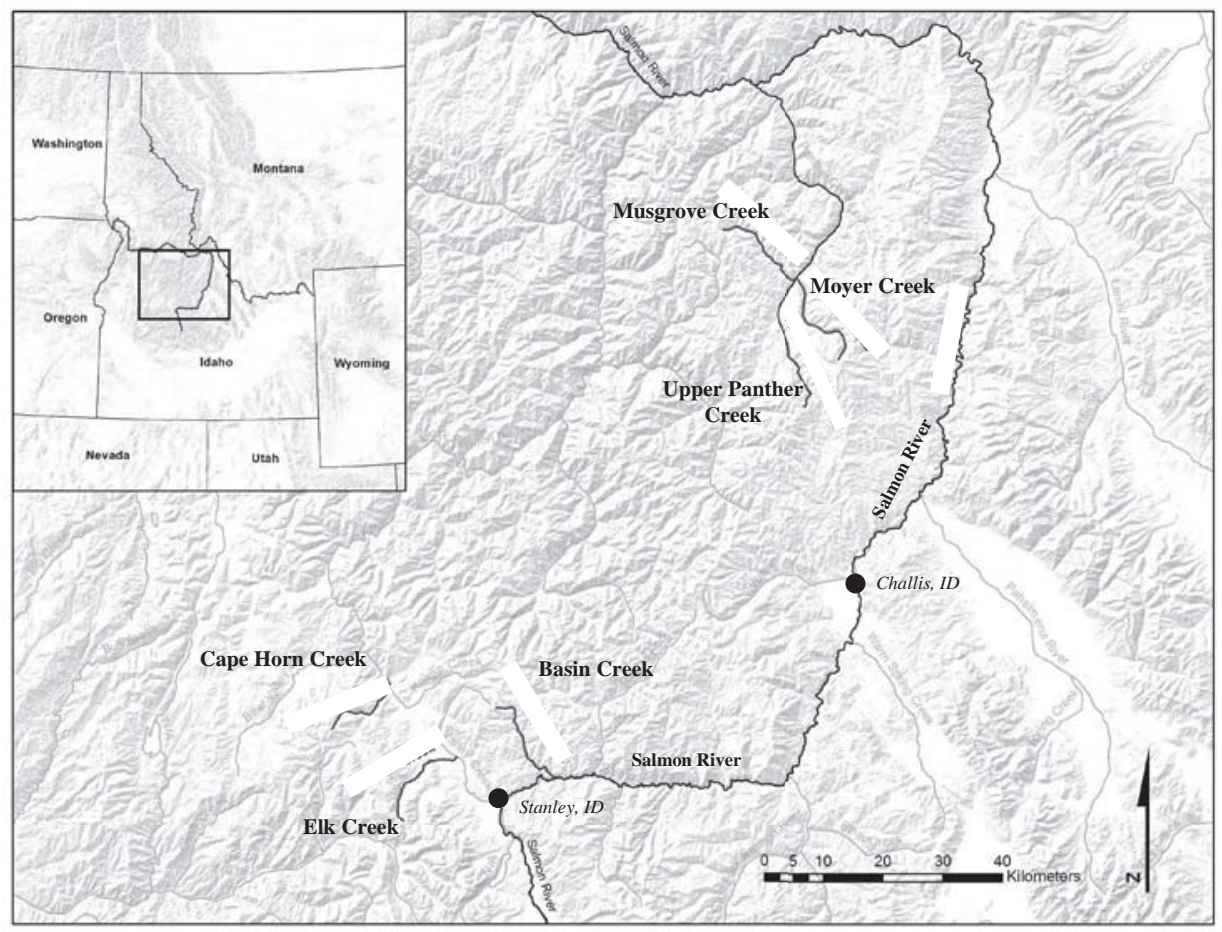

Figure 2.2 Location of study streams in central Idaho (inset, upper-right).

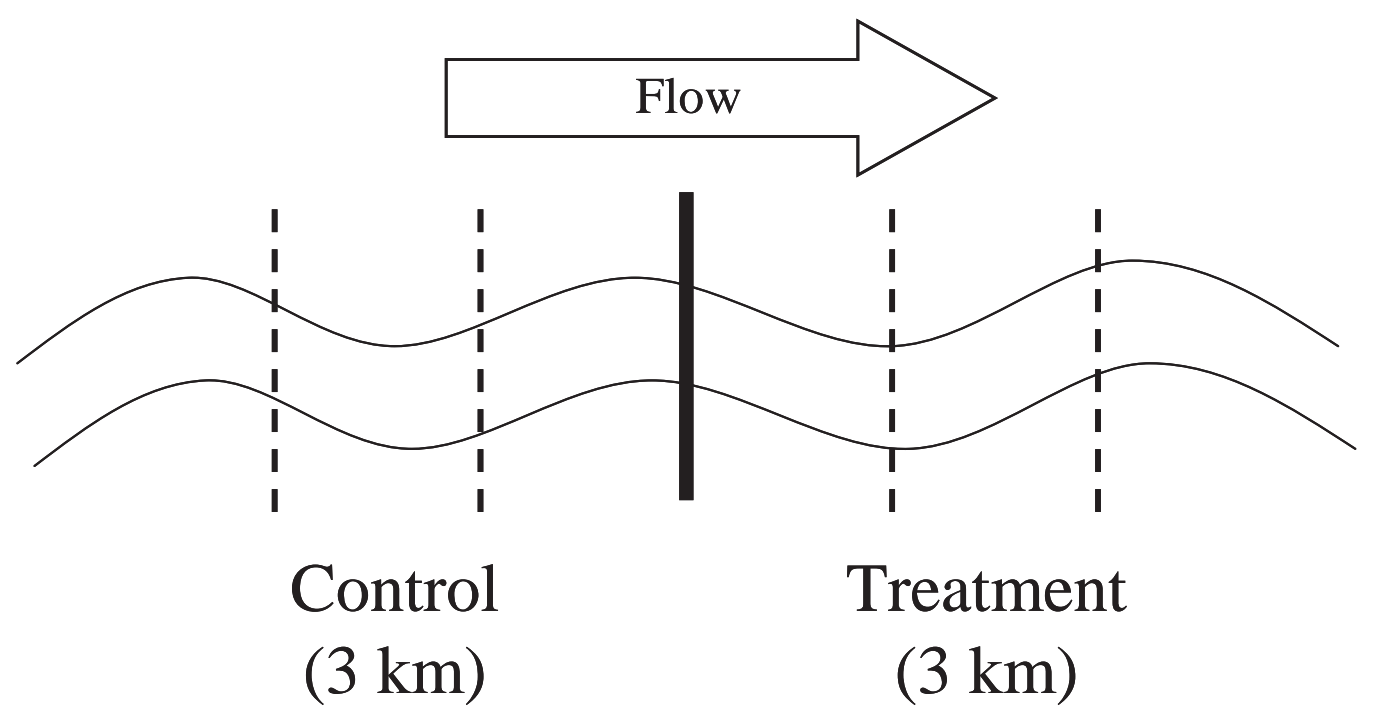

Figure 2.3 Schematic of study design. Upstream control and downstream treatment segments are separated by a solid black line. In 2010, study segments were further stratified into $1 \mathrm{~km}$ reaches as indicated by the dashed lines. 


\subsection{Physical characteristics}

We measured stream channel and watershed characteristics in 2011. Stream depth and stream flow velocity was measured at $25 \mathrm{~cm}$ intervals along three transects in each segment with a calibrated wading rod and a Marsh McBirney Flo-Mate Model 2000 flow meter, respectively. Depth and flow velocity measurements across transects were used to calculate discharge. Temperature was measured at 15 minute intervals from JulySeptember 2011 using HOBO temperature loggers at the midpoint of each study segment. We estimated canopy cover at all biofilm standing crop sample collection sites (see Section 2.3) with a spherical densitometer. Habitat measurements within each segment were averaged. Basin area draining to the downstream edge of each segment was determined with the USGS StreamStats web application. We calculated channel gradient of segments by dividing the difference in elevation between the upstream and downstream boundaries of each segment by the total length of the segment. Physical stream and watershed characteristics are shown in Table 2.1. 


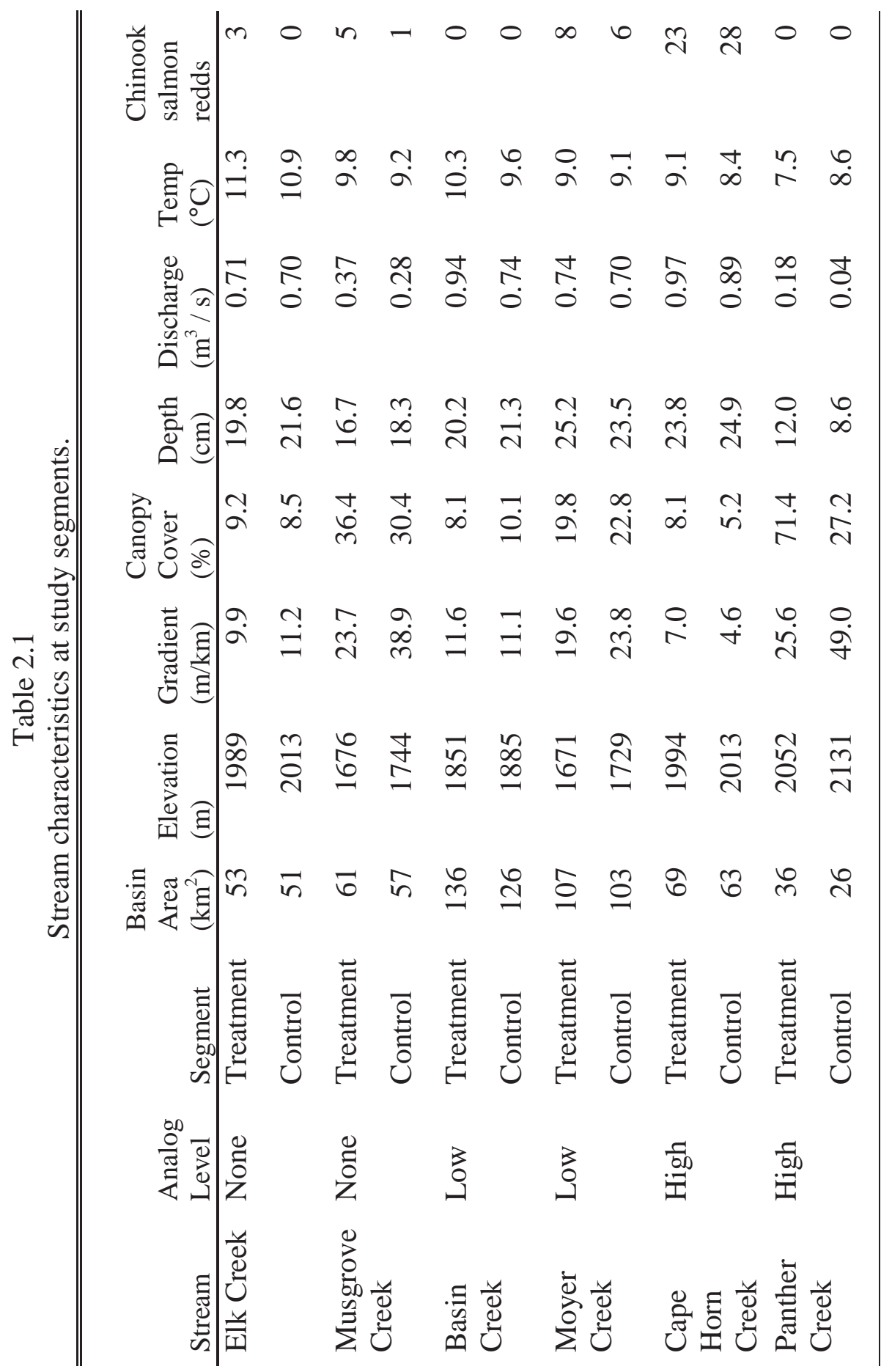




\subsection{Biofilm Standing Crop}

We measured biofilm standing crop on natural substrates as chlorophyll $a$ and ash free dry mass (AFDM) two weeks prior and four weeks after analog addition in both 2010 and 2011. In 2010, we stratified our $3 \mathrm{~km}$ control and treatment segments into $1 \mathrm{~km}$ upper, middle, and lower reaches. We collected three rocks from each of two randomly selected riffles within the three reaches. In 2011, we removed the within-segment stratification and collected three rocks from nine randomly selected riffles along each study segment. Our sampling protocol for collecting biofilm substrates changed between years because our initial sampling design did not provide sufficient statistical power to detect subtle differences. The change in sampling design increased our power to detect differences in both chlorophyll $a$ and AFDM (Table 2.2, Table 2.3).

Biofilms were scrubbed from rocks into approximately $400 \mathrm{~mL}$ of stream water and the resultant slurry was filtered through $0.7 \mu \mathrm{m}$ glass-fiber filters. Filters were frozen for storage and transportation before being analyzed for chlorophyll $a$ and AFDM according to standard methods (APHA 2005). To obtain an estimate of standing crop per $\mathrm{m}^{2}$ of substrate, we determined rock surface area by tracing the planar area onto paper and weighing the cut-out (Bergey and Getty 2006). We analyzed the difference in standing crop between treatment and control segments (i.e., treatment minus control) using a two-way analysis of variance (ANOVA) with analog level (no analog, low analog, high analog) and sampling period (before, after) as fixed factors. We explored the whether physical characteristics of our study segments influenced biofilm standing crop using simple linear regressions. Chlorophyll $a$ and AFDM values were log-transformed 
before all analyses to meet statistical assumptions of residual normality. Percent canopy

cover was also log transformed to reduce skewness of the residuals caused by one

segment with substantially higher canopy cover than other 11 segments.

Table 2.2

Power analysis for chlorophyll $a$ in summer 2010 and 2011, analyzed as the difference between treatment and control segments within streams. Two-tailed power tests were calculated with a confidence level of 5\%. Ideal sample sizes were calculated using a confidence level of 5\% and a beta error level of 50\%. Calculations made at http://www.dssresearch.com/KnowledgeCenter/toolkitcalculators/samplesizecalculators.a

\begin{tabular}{cllll}
\multicolumn{5}{c}{$\mathrm{spx}$} \\
\hline \hline Year & Comparison & $\begin{array}{l}\text { Analog (mean } \\
\text { T-C } \pm \text { SD }\end{array}$ & $\begin{array}{l}\text { No Analog } \\
\text { (mean T-C } \pm\end{array}$ & $\begin{array}{l}\text { Analog vs } \\
\text { Control } \\
\text { (power; } \\
\text { sample size) }\end{array}$ \\
\hline 2010 & $\begin{array}{l}\text { High v. No } \\
\text { Analog }\end{array}$ & $6.01 \pm 12.02$ & $3.53 \pm 14.60$ & $7.3 \% ; 157$ \\
& $\begin{array}{l}\text { Low v. No } \\
\text { Analog }\end{array}$ & $-5.65 \pm 8.29$ & $3.53 \pm 14.60$ & $19.2 \% ; 9$ \\
2011 & $\begin{array}{l}\text { High v. No } \\
\text { Analog } \\
\end{array}$ & $1.59 \pm 4.21$ & $5.62 \pm 6.53$ & $18.1 \% ; 7$ \\
& $\begin{array}{l}\text { Low v. No } \\
\text { Analog }\end{array}$ & $0.15 \pm 2.04$ & $5.62 \pm 6.53$ & $30.4 \% ; 4$ \\
\hline
\end{tabular}

Table 2.3

Power analysis for AFDM in summer 2010 and 2011, analyzed as the difference between treatment and control segments within streams (mean T-C). Two-tailed power tests were calculated with a confidence level of 5\%. Ideal sample sizes were calculated using a confidence level of 5\% and a beta error level of $50 \%$. Calculations made at http://www.dssresearch.com/KnowledgeCenter/toolkitcalculators/samplesizecalculators.a

\begin{tabular}{|c|c|c|c|c|}
\hline Year & Comparison & $\begin{array}{l}\text { Analog (mean } \\
\mathrm{T}-\mathrm{C} \pm \mathrm{SD}\end{array}$ & $\begin{array}{l}\text { No Analog } \\
\text { (mean T-C } \pm \\
\text { SD) }\end{array}$ & $\begin{array}{l}\text { Analog vs } \\
\text { Control } \\
\text { (power) }\end{array}$ \\
\hline \multirow[t]{4}{*}{2010} & High v. No & $61.75 \pm$ & & \\
\hline & Analog & 145.54 & $11.82 \pm 41.72$ & $11.9 \% ; 25$ \\
\hline & Low v. No & & & \\
\hline & Analog & $-3.82 \pm 67.39$ & $11.82 \pm 41.72$ & $8.6 \% ; 69$ \\
\hline \multirow{3}{*}{2011} & $\begin{array}{l}\text { Hign V. No } \\
\text { Analog }\end{array}$ & $0.27 \pm 0.58$ & $2.13 \pm 2.31$ & $29.4 \%: 4$ \\
\hline & Low v. No & & & \\
\hline & Analog & $0.97 \pm 1.68$ & $2.13 \pm 2.31$ & $14.2 \% ; 16$ \\
\hline
\end{tabular}




\subsection{Nutrient limitation}

We deployed nutrient diffusing substrates (NDS) in each study segment 4 weeks prior to analog addition in 2010 and one week after analog addition during 2010 and 2011 to examine whether analog addition altered biofilm nutrient limitation. NDS consisted of $37 \mathrm{ml}$ PolyCon vials filled with a nutrient amended agar and capped with a 24-mm diameter fritted glass disk. Nutrients diffused out of the agar and through the glass disk which provided a substrate for biofilm colonization. The rate of diffusion is not greatly affected by temperature, but is strongly dependent on the nutrient concentration in the agar and diffusion rates decrease log-linearly with time (Rugenski et al. 2008). NDS were amended with 0.8 mol nitrogen $\mathrm{L}^{-1}$ as $\mathrm{NaNO}_{3}, 0.05$ mol phosphorus $\mathrm{L}^{-1}$ as $\mathrm{KH}_{2} \mathrm{PO}_{4}$, or both $\mathrm{N}+\mathrm{P}$. Nitrogen and phosphorus concentrations in substrates were designed to diffuse at a rate greater than algal uptake and, thus, remove the possibility of biofilm nutrient limitation for that amendment. NDS containing agar only (i.e., no added nutrient) served as our control. Six replicates of each amendment were placed in metal racks installed at the downstream edge of each segment. Following a 21 day deployment, fritted glass disks were wrapped in aluminum foil and frozen until analysis of chlorophyll $a$ and AFDM by standard methods (APHA 2005).

We determined nutrient limitation of biofilms in individual study segments using a two-way ANOVA with $\mathrm{N}$ and $\mathrm{P}$ as fixed factors. To examine the effect of analog treatments on nutrient limitation, we used a three way ANOVA with amendment $(\mathrm{N}, \mathrm{P}$, $\mathrm{N}+\mathrm{P}$, No Nutrient), segment (treatment, control) and analog level (no analog, low analog, high analog) as factors. Chlorophyll $a$ concentration and AFDM on NDS were log- 
transformed before all analyses to meet the normality assumptions of a factorial ANOVA.

\subsection{Metabolism}

\subsubsection{Whole-stream metabolism}

We measured whole-stream metabolism with dissolved oxygen records from control and treatment segments of Basin Creek (low analog) and Cape Horn Creek (high analog) to assess whether analog addition increased microbial metabolic activity. Ecosystem metabolism can exhibit high day-to-day variability (Roberts et al. 2007), thus metabolism estimates based on short periods (i.e., 2-3 days) of continuous dissolved oxygen records may not accurately represent changes in metabolism due to analog addition. We estimated metabolism in control and treatment segments of only two streams in order maximize the length of continuous dissolved oxygen records to encompass day-to-day variability in metabolism and ensure that we were measuring a metabolism response to analog addition rather a response to changing weather patterns. Whole-stream metabolism was estimated from records of dissolved oxygen and temperature collected at 10 minute intervals between August $30^{\text {th }}$ and September $26^{\text {th }}$, 2011 with YSI 6920 V2 water quality sondes equipped with YSI 6150+ ROX optical dissolved oxygen probes. Dissolved oxygen probes were calibrated before initial deployment and again 18 days after deployment using the saturated air technique. Daily metabolism was calculated for control and treatment segments using the single station open water method (Bott 2006). We used diel changes in oxygen concentration over a 24- 
$\mathrm{h}$ period to estimate net ecosystem production (NEP as $\mathrm{mg} \mathrm{O}_{2} \mathrm{~m}^{-2} \mathrm{~d}^{-1}$ ) according to the equation

$$
\operatorname{NEP}(\mathrm{dt})=\left(\mathrm{C}_{\mathrm{t}}-\mathrm{C}_{\mathrm{t}-1}\right) / \mathrm{dt}-\mathrm{k}\left(\mathrm{C}_{\mathrm{s}}-\mathrm{C}_{\mathrm{t}}\right)+\mathrm{A}
$$

Where: $\mathrm{t}=$ time, $\mathrm{C}_{\mathrm{t}}=\mathrm{O}_{2}$ concentration at a single time step, $\mathrm{C}_{\mathrm{s}}=$ saturation constant of $\mathrm{O}_{2}$ in water, $\mathrm{k}=$ reaeration coefficient (i.e., $\mathrm{O}_{2}$ exchange between water and the atmosphere), and $\mathrm{A}=\mathrm{O}_{2}$ exchange between the stream and groundwater. Daily ecosystem respiration (ER as $\mathrm{mg} \mathrm{O}_{2} \mathrm{~m}^{-2} \mathrm{~d}^{-1}$ ) was estimated by averaging NEP over the night-time period, then extrapolating this average rate over the entire $24 \mathrm{~h}$ period. Daily gross primary productivity (GPP as $\mathrm{mg} \mathrm{O}_{2} \mathrm{~m}^{-2} \mathrm{~d}^{-1}$ ) was calculated as the sum of NEP and ER. We potentially underestimated GPP and overestimated ER because we did not account for $\mathrm{O}_{2}$ exchange between the stream and groundwater (A) in our calculations (Hall and Tank 2005). We automated whole stream metabolism calculations with the RIVERMET tool (Izagirre et al. 2007).

The use of diel oxygen curves for whole stream metabolism requires accurate estimates of oxygen flux between the stream and the atmosphere (reaeration coefficient; k). We could not robustly estimate reaeratation with direct gas evasion (Marzolf et al. 1994; Young and Huryn 1998) because of the high width to depth ratio of our study streams. Therefore, we employed multiple different models to estimate reaeration. First, we used the night-time regression method of Hornberger and Kelly (1975), which regresses the night-time decrease in $\mathrm{O}_{2}$ per time unit $\left(\mathrm{dt}^{-1}\right)$ against the oxygen saturation deficit. The reaeration coefficient is estimated from the slope of the regression. Days with non-significant night-time regressions were not included in the analysis. Because nighttime regression does not always provide robust estimates of $\mathrm{k}$ in streams less than $0.5 \mathrm{~m}$ 
in depth (Young and Huryn 1999; Aristegi et al. 2009), we also used morphologic and hydrologic characteristics of segments (i.e., slope, depth, discharge, water velocity) to calculate k using fitted equations (E1-E6; Raymond et al. 2012), a fitted equation for pool-riffle stream systems (E7; Melching and Flores 1999), and the energy dissipation model (E8; Tsivoglou and Neal 1976) (Table 2.4). When solved, E1-6 produced a gas transfer velocity normalized to a Schmidt number (Sc) of 600 (i.e., temperaturedependent ratio of kinematic viscosity of water and the diffusion coefficient of a gas). We converted predicted $\mathrm{k}_{600}$ to $\mathrm{k}_{20}$ for input to RIVERMET by first converting $\mathrm{k}_{600}$ to gas transfer velocity for oxygen at $17.5^{\circ} \mathrm{C}\left(\mathrm{k}_{02}\right.$ at $\left.17.5^{\circ} \mathrm{C}\right)$ followed by adjusting $\mathrm{k}_{02}$ at $17.5^{\circ} \mathrm{C}$

Table 2.4

Empirical equations used to calculate the reaeration coefficient.

\begin{tabular}{|c|c|c|}
\hline Code & Equation & Citation \\
\hline E1 & $\mathrm{k}_{600}=(\mathrm{VS})^{0.89} \times \mathrm{D}^{0.54} \times 5037$ & Raymond et al. (2012) \\
\hline E2 & $\mathrm{k}_{600}=1162 \times \mathrm{S}^{0.77} \times \mathrm{V}^{0.85}$ & Raymond et al. (2012) \\
\hline E3 & $\mathrm{k}_{600}=(\mathrm{VS})^{0.76} \times 951.5$ & Raymond et al. (2012) \\
\hline E4 & $\mathrm{k}_{600}=(\mathrm{VS}+2841)+2.02$ & Raymond et al. (2012) \\
\hline E5 & $\mathrm{k}_{600}=929 \times(\mathrm{VS})^{0.75} \times \mathrm{Q}^{0.011}$ & Raymond et al. (2012) \\
\hline E6 & $\mathrm{k}_{600}=4725 \times(\mathrm{VS})^{0.86} \times \mathrm{Q}^{-0.14} \times \mathrm{D}^{0.66}$ & Raymond et al. (2012) \\
\hline E7 & $\mathrm{k}_{20}=596 \times(\mathrm{VS})^{0.528} \times \mathrm{Q}^{-0.136}$ & Melching and Flores (1999) \\
\hline E8 & $\mathrm{k}_{20}=\mathrm{k}^{\prime} * \mathrm{~S} * \mathrm{~V}$ & Tsivoglou and Neal (1976) \\
\hline \multicolumn{3}{|c|}{$\begin{array}{l}\mathrm{k}_{600} \text { is the gas transfer velocity with a Schmidt number of } 600, \mathrm{k}_{20} \text { is the reaeration } \\
\text { coefficient at } 20^{\circ} \mathrm{C} . \mathrm{V}=\text { stream velocity in } \mathrm{m} \mathrm{s}^{-1} ; \mathrm{S}=\text { slope; } \mathrm{Q}=\text { discharge in } \mathrm{m}^{3} \mathrm{~s}^{-1} \text {; } \\
\mathrm{D}=\text { depth in meters for E1-E7 \& E8); } \mathrm{k}^{\prime}=1.53 \times 10^{4} \mathrm{~s} \mathrm{~m}^{-1} \mathrm{~d}^{-1} \text { for stream flow }>560 \\
\mathrm{~L} \mathrm{~s}^{-1} \text {. }\end{array}$} \\
\hline
\end{tabular}

to $\mathrm{k}_{02}$ at $20^{\circ} \mathrm{C}$ according to the known temperature dependency of Schmidt numbers for oxygen $\left(\mathrm{Sc}_{\mathrm{O} 2}=1568-86.04 \mathrm{~T}+2.142 \mathrm{~T}^{2}-0.0216 \mathrm{~T}^{3}\right.$, where $\mathrm{T}=$ temperature in ${ }^{\circ} \mathrm{C}$; Raymond et al. 2012), and dividing $\mathrm{k}_{02}$ at $20^{\circ} \mathrm{C}$ by mean segment depth (D, in meters) using the following equation: 


$$
\mathrm{k}_{20}=\left[\mathrm{k}_{600} /\left(600 / \mathrm{Sc}_{\mathrm{O} 2}\right)^{-0.5}\right] / \mathrm{D}, \text { units: } \mathrm{d}^{-1}
$$

We examined differences in whole-stream metabolism between segments by visually comparing time-series plots of GPP, ER, and NEP.

\subsubsection{Benthic Metabolism}

In 2011, we also measured benthic metabolism in small light-dark re-circulating chambers using short-term incubations in treatment and control segments of Cape Horn Creek (high analog), Basin Creek (low analog), and Elk Creek (no analog) near Stanley, Idaho. Chambers were constructed from 2-L polycarbonate containers with inlet and outlet openings connected with Tygon tubing to submersible centrifugal bilge pumps. Substrates were haphazardly collected from riffles and incubated in the chambers for 1-2 hrs in full sunlight. We used micro-Winkler titrations (APHA 2005) to measure dissolved oxygen in chambers at the beginning and end of incubations. Clear chambers were used to measure net community productivity (NCP) because changes in dissolved oxygen in the presence of light can be attributed to algal photosynthesis and to respiration by both autotrophs and heterotrophs. We use the term net community respiration to highlight the differences between whole-stream and benthic metabolism; whole-stream metabolism accounts for respiration by all organisms in the stream and the hyporheic zone whereas chambers are used to measure the metabolic activity of only biofilms communities on streambed rocks. Respiration was measured in dark chambers because changes in oxygen can be attributed only to respiration when light is absent. At the end of each incubation period, biofilm standing crop and rock surface area was measured as described in Section 
2.3. NCP and $\mathrm{R}$ were determined from dissolved oxygen measurements in light and dark chambers, respectively, using equations from Wetzel and Likens (2000):

$$
\begin{gathered}
\mathrm{NCP}\left(\mathrm{mg} \mathrm{C} \mathrm{m}^{-2} \mathrm{~h}^{-1}\right)=\left[\left(\mathrm{DO}_{\text {before }}-\mathrm{DO}_{\text {after }}\right)(\mathrm{V})(0.375)\right] /(\mathrm{t})(\mathrm{SA})(\mathrm{PQ}) \\
\mathrm{R}\left(\mathrm{mg} \mathrm{C} \mathrm{m}^{-2} \mathrm{~h}^{-1}\right)=\left[\left(\mathrm{DO}_{\text {before }}-\mathrm{DO}_{\text {after }}\right)(\mathrm{V})(\mathrm{RQ})(0.375)\right] /(\mathrm{t})(\mathrm{SA})
\end{gathered}
$$

Where $\mathrm{t}=$ time, $\mathrm{DO}_{\text {before }}$ and $\mathrm{DO}_{\text {after }}=$ dissolved oxygen concentrations before and after incubation respectively, $\mathrm{V}=$ water volume in chamber (i.e., volume of chamber, tubing and pump minus volume of stream substrate), $\mathrm{SA}=$ surface area of stream substrate, $\mathrm{PQ}$ $=$ photosynthetic quotient (i.e., the ratio of $\mathrm{O}_{2}$ production to inorganic carbon fixation; assumed to be 1 ), $R Q=$ respiratory quotient (i.e., the efficiency of converting $\mathrm{O}_{2}$ to carbon through metabolism; assumed to be 1 ). The value 0.375 is a constant determined by the molar ratio of carbon to $\mathrm{O}_{2}$ (Wetzel and Likens 2000). GPP was calculated as the sum of NCP + ER.

We assessed differences in NCP and R between control and treatment segments using t-tests. Because we used multiple t-tests, we employed a bonferroni-correction to our alpha value $\left(\alpha_{\text {bonferroni }}=0.05 / 3=0.017\right)$. 


\section{RESULTS}

\subsection{Biofilm Standing Crop}

Our results show that biofilm and chlorophyll $a$ and AFDM did not respond to analog addition under any analog level in 2010 (Figure 3.1) or 2011 (Figure 3.2). There were no significant differences in chlorophyll $a$ or AFDM between control and treatment segments during before and after analog addition sampling periods under any analog level in either 2010 or 2011 (Table 3.1). The lack of difference between standing crop in treatment and control segments was consistent across sampling periods regardless of analog level.

Many of the physical characteristics we measured in our study were autocorrelated. Discharge was significantly correlated with depth $\left(\mathrm{p}<0.001, \mathrm{r}^{2}=0.776\right)$, velocity $\left(\mathrm{p}=0.009, \mathrm{r}^{2}=0.515\right)$, gradient $\left(\mathrm{p}<0.001, \mathrm{r}^{2}=0.722\right)$, and basin area $(\mathrm{p}=$ $\left.0.028, r^{2}=0.396\right)$. Canopy cover was negatively correlated with discharge $\left(p=0.002, r^{2}\right.$ $=0.639$ ), which is not surprising because higher discharge streams in our system tend to be wider than streams with lower discharges. Canopy cover differed significantly between the two geographic groups of streams $\left(t_{5}=3.41, p=0.019\right)$, as did discharge $\left(\mathrm{t}_{5}=3.47, \mathrm{p}=0.013\right)$. Despite the correlation between canopy cover and discharge, we regressed biofilm standing crop against both of these variables. Contrary to our expectations, chlorophyll $a$ was positively associated with canopy cover (Figure 3.3a), and negatively associated with discharge (Figure 3.3b). AFDM was not correlated with canopy cover $\left(\mathrm{p}=0.304, \mathrm{r}^{2}=0.105\right)$ or discharge $\left(\mathrm{p}=0.485, \mathrm{r}^{2}=0.050\right)$. 

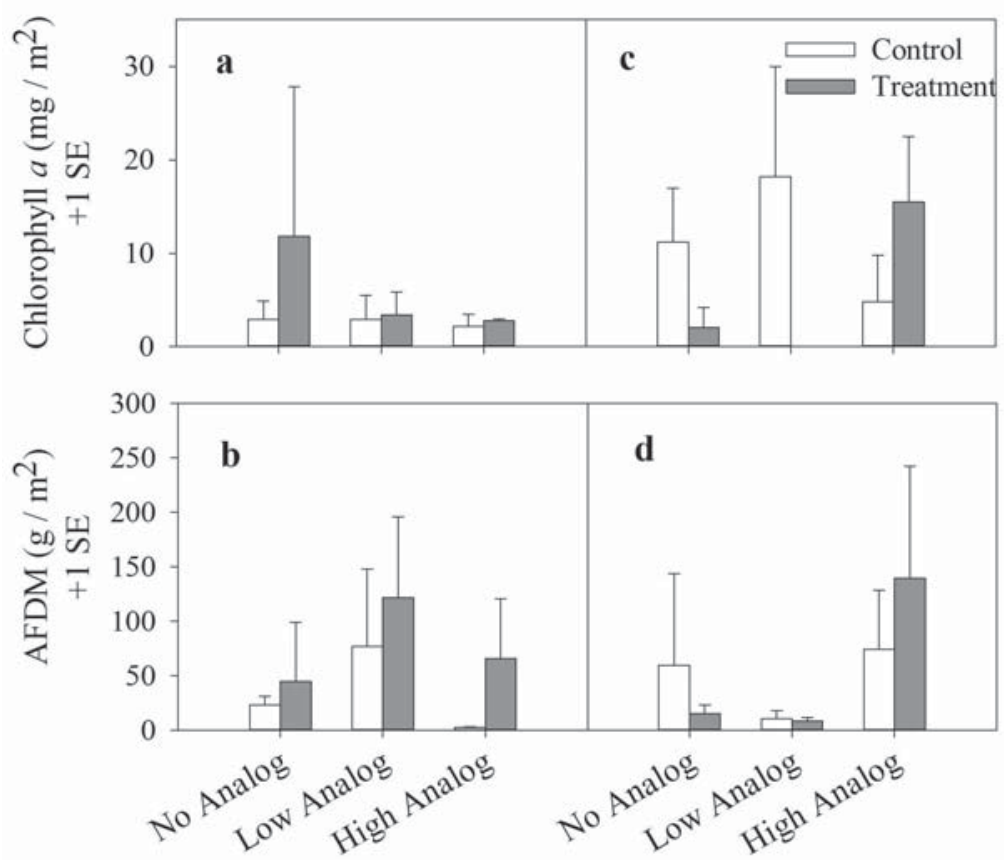

Figure 3.1 Chlorophyll $a$ and AFDM on natural substrates collected before $(a, b)$ and after $(c, d)$ analog addition in 2010. $\mathrm{n}=2$ for all error bars. Post-addition chlorophyll $a$ samples from low analog treatment segments were lost during analysis.
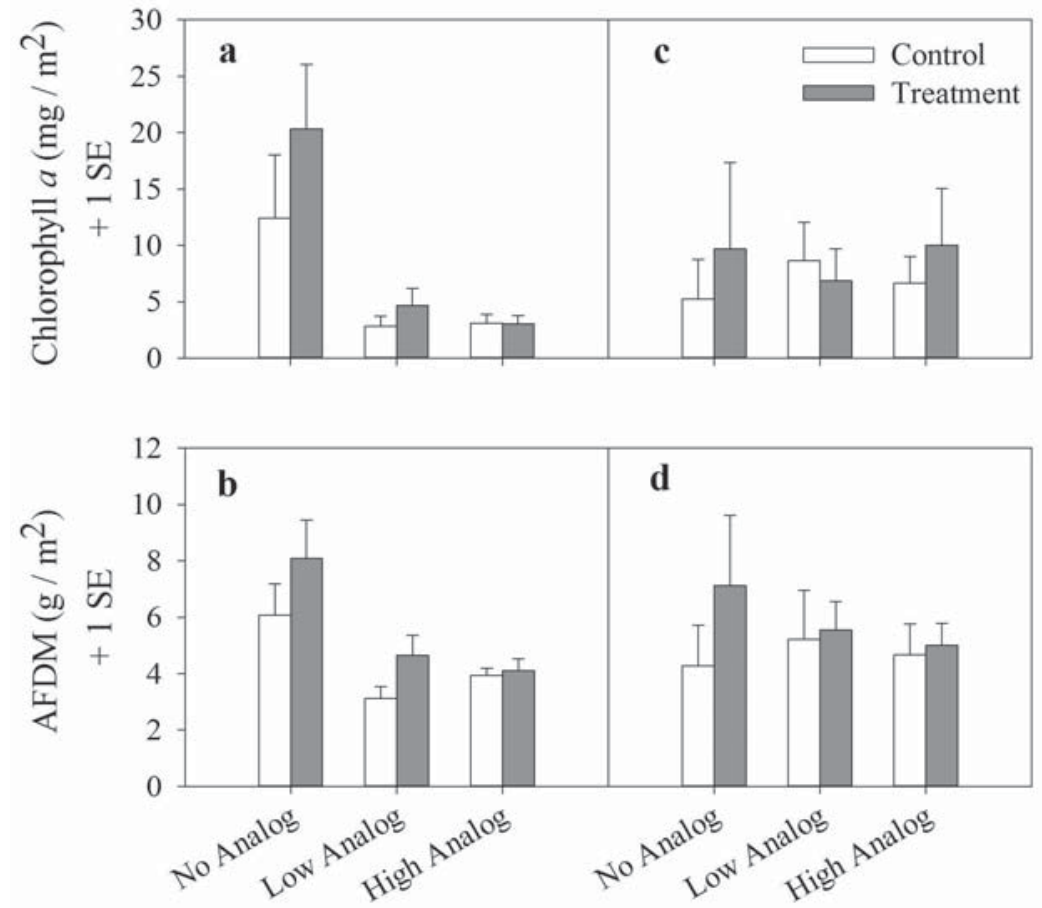

Figure 3.2 Chlorophyll $a$ and AFDM on natural substrates collected before $(a, b)$ and after $(c, d)$ analog addition in 2011. $\mathrm{n}=2$ for all error bars. 
Table 3.1

Two-way ANOVA results for 2010 and 2011 Chlorophyll $a$ and AFDM on natural substrates with sample period (levels = Before, After) and Analog Level (levels = High, Low, No Analog) as fixed factors.

\begin{tabular}{|c|c|c|c|c|c|c|c|c|}
\hline & \multicolumn{4}{|l|}{2010} & \multicolumn{4}{|l|}{2011} \\
\hline & \multicolumn{2}{|c|}{ Chlorophyll a } & \multicolumn{2}{|l|}{ AFDM } & \multicolumn{2}{|c|}{ Chlorophyll a } & \multicolumn{2}{|l|}{ AFDM } \\
\hline & $F$ & $p$ & $F$ & $p$ & $F$ & $p$ & $F$ & $p$ \\
\hline Level & $1.02_{2,6}$ & 0.415 & $0.32_{2,6}$ & 0.735 & $1.18_{2,6}$ & 0.370 & $0.900_{2,6}$ & 0.456 \\
\hline BA & $0.48_{1,6}$ & 0.514 & $0.15_{1,6}$ & 0.713 & $0.06_{1,6}$ & 0.817 & $0.010_{1,6}$ & 0.943 \\
\hline Level*BA & $1.40_{2,6}$ & 0.316 & $0.10_{2,6}$ & 0.903 & $0.51_{2,6}$ & 0.625 & $0.240_{2,6}$ & 0.796 \\
\hline
\end{tabular}

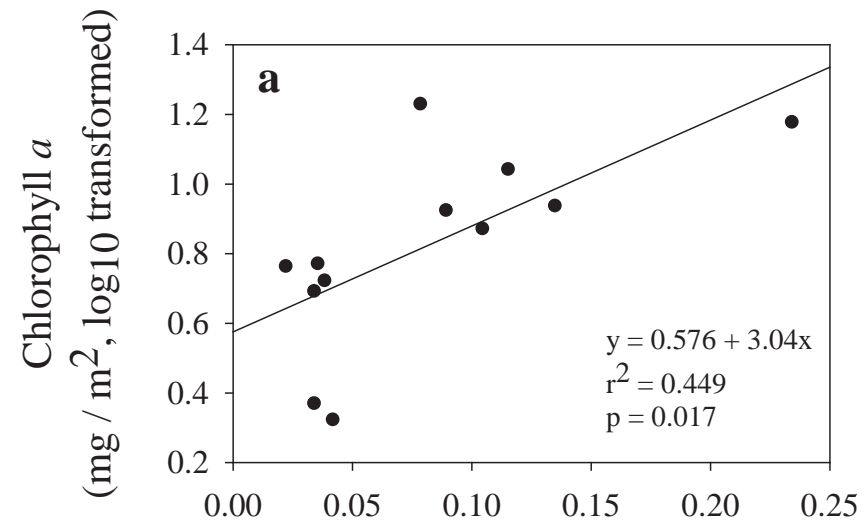

Canopy Cover $(\log 10 \mathrm{x}+1$ transformed)

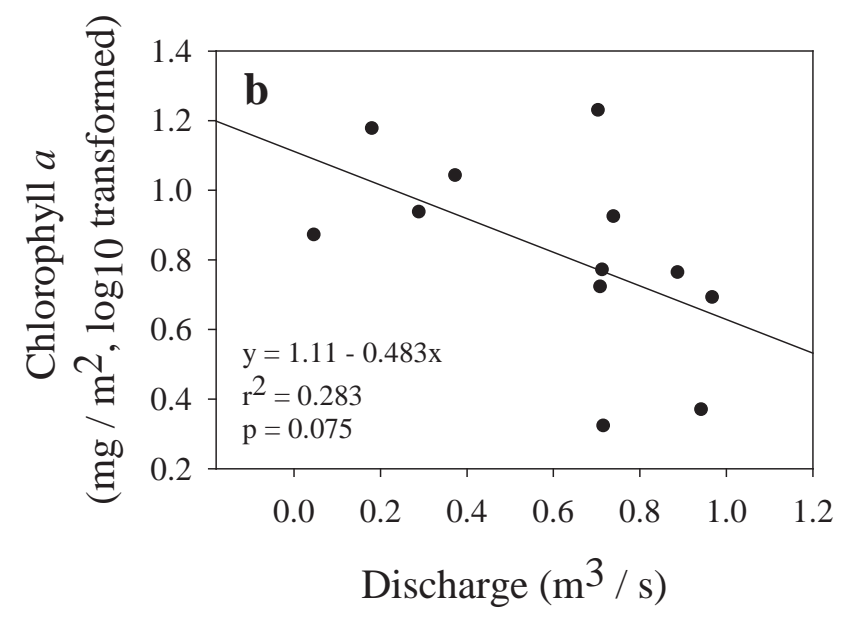

Figure 3.3. Relationship of chlorophyll $a$ concentration on rocks collected after analog addition in 2011 with $(a)$ canopy cover and $(b)$ discharge $\left(\mathrm{m}^{3} / \mathrm{s}\right)$. 


\subsection{Nutrient Limitation}

Biofilms in study streams were primarily N-limited and nutrient limitation did not change with analog addition (Level X Segment X Amendment; Table 3.1). Chlorophyll $a$ and AFDM on nutrient diffusing substrates deployed in treatment segments before analog addition in July 2010 showed similar nutrient limitation patterns to substrates deployed in the same segment after the 2010 analog addition (Table 3.3). Chlorophyll $a$ exhibited primary N-limitation in five of six treatment segments following analog addition during the post-analog period of both study years (Table 3.3), whereas primary N-limitation of chlorophyll $a$ occurred in four and five control segments during the post-analog addition periods of 2010 and 2011, respectively (Table 3.3). After analog addition, $\mathrm{N}$ amendments in control and treatment segments stimulated AFDM accrual in two and three streams in 2010 and 2011, respectively (Table 3.4). Primary P-limitation was rare for biofilms in our streams, and occurred for AFDM in only one segment during July 2010.

Analog addition altered the amount of chlorophyll $a$ on substrates, as indicated by a significant Level X Segment interaction (Table 3.2). Under the high analog addition, chlorophyll $a$ was 2.2, 1.6 and 2 times higher on no nutrient, nitrogen, and $\mathrm{N}+\mathrm{P}$ amended substrates in high analog segments than control segments in 2010. In the same high analog streams, NDS deployed in 2011 chlorophyll $a$ was 3, 1.8, and 4 times higher on no nutrient, nitrogen and phosphorus amended substrates in treatment segments than control segments and only 1.1 times higher for $\mathrm{N}+\mathrm{P}$ amendments (Figure 3.4). This pattern was not observed in AFDM (Figure 3.5). 
Table 3.2

Three-way ANOVA results on chlorophyll $a$ concentrations on nutrient diffusing substrates deployed after analog addition in 2010 and 2011. Analog level (no analog, low, high), segment (treatment, control), amendment (no nutrient, $\mathrm{N}, \mathrm{P}, \mathrm{N}+\mathrm{P}$ ) were fixed factors. The response variable was log-transformed chlorophyll $a\left(\mathrm{mg} / \mathrm{m}^{2}\right)$. F-ratios with degrees of freedom are shown and significant differences are indicated with a (*).

\begin{tabular}{lrrrr}
\hline \hline & \multicolumn{3}{c}{2011} \\
\cline { 2 - 6 } Factor & \multicolumn{1}{c}{ F } & \multicolumn{2}{c}{$F$} & \multicolumn{2}{c}{$p$} \\
\hline Level & $6.77_{2,245}$ & $* 0.001$ & $4.51_{2,209}$ & $* 0.012$ \\
Segment & $8.08_{1,245}$ & $* 0.005$ & $10.93_{1,209}$ & $* 0.001$ \\
Amendment & $58.96_{3,245}$ & $*<0.001$ & $36.18_{3,209}$ & $*<0.001$ \\
Level*Segment & $8.11_{2,245}$ & $*<0.001$ & $5.84_{2,209}$ & $* 0.003$ \\
Level*Amendment & $3.51_{6,245}$ & $* 0.002$ & $0.51_{6,209}$ & 0.799 \\
Segment*Amendment & $1.29_{3,245}$ & 0.277 & $1.35_{3,209}$ & 0.260 \\
Level*Segment*Amendment & $1.51_{6,245}$ & 0.174 & $0.78_{6,209}$ & 0.583 \\
\hline
\end{tabular}




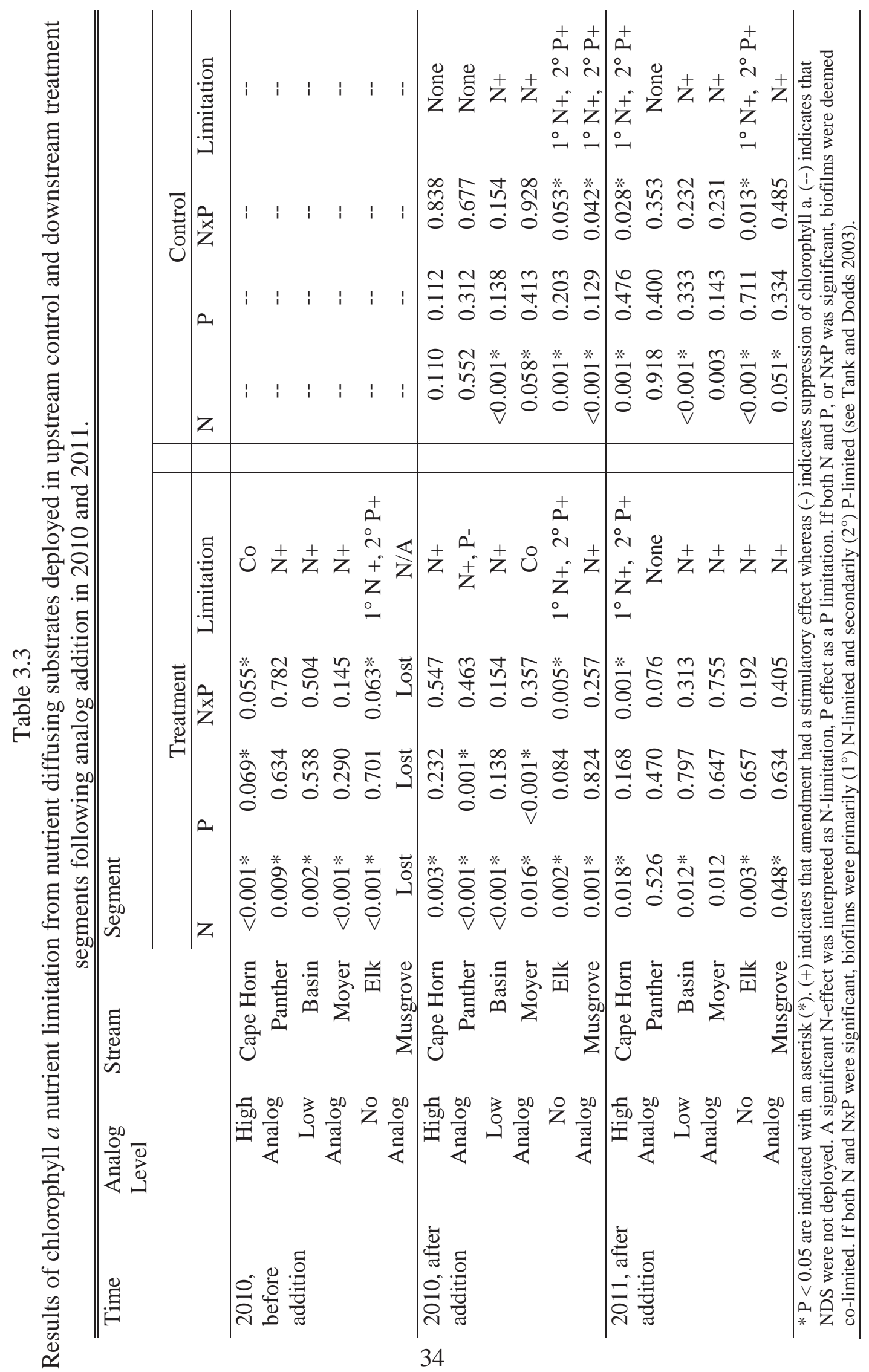




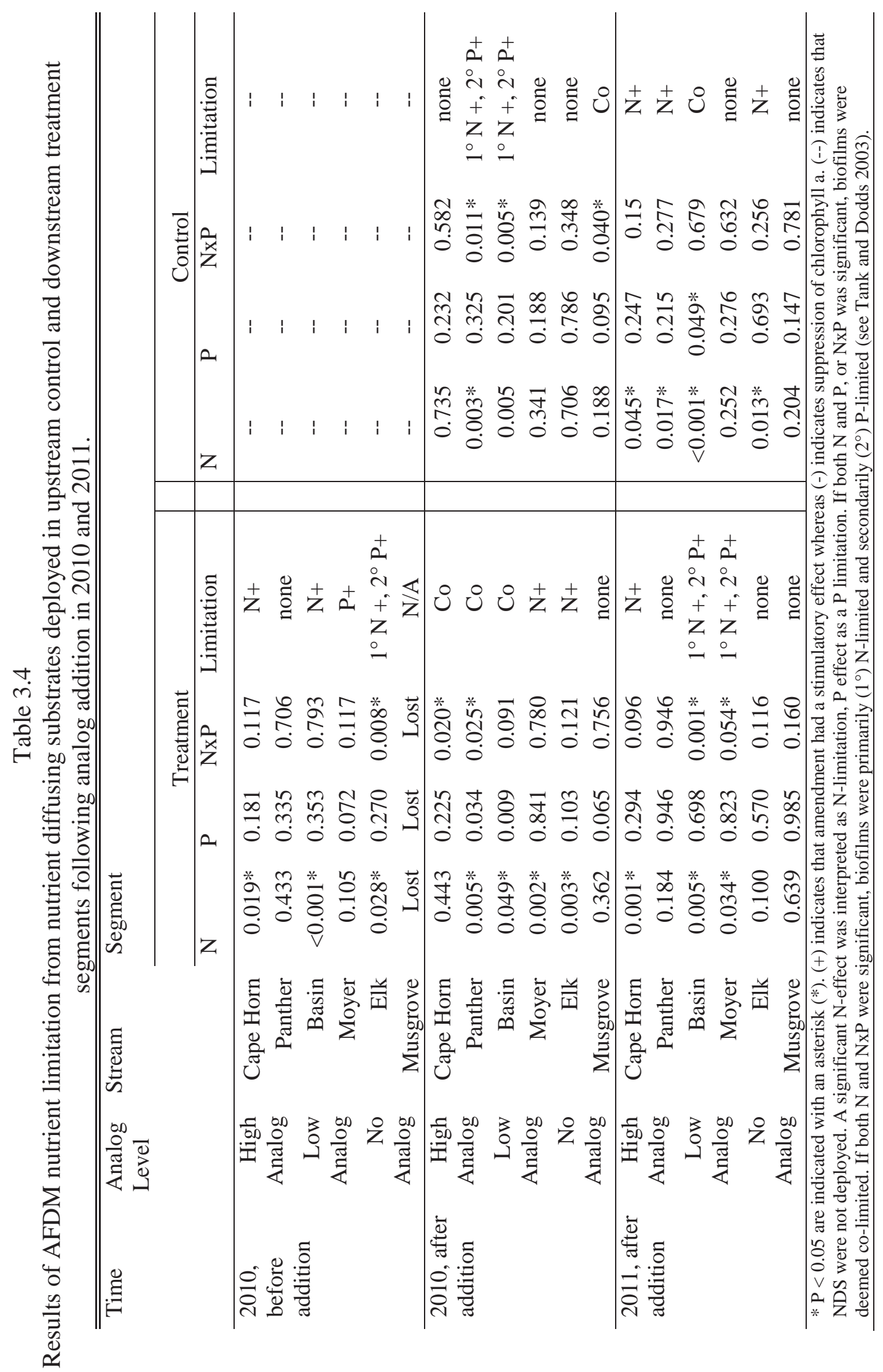




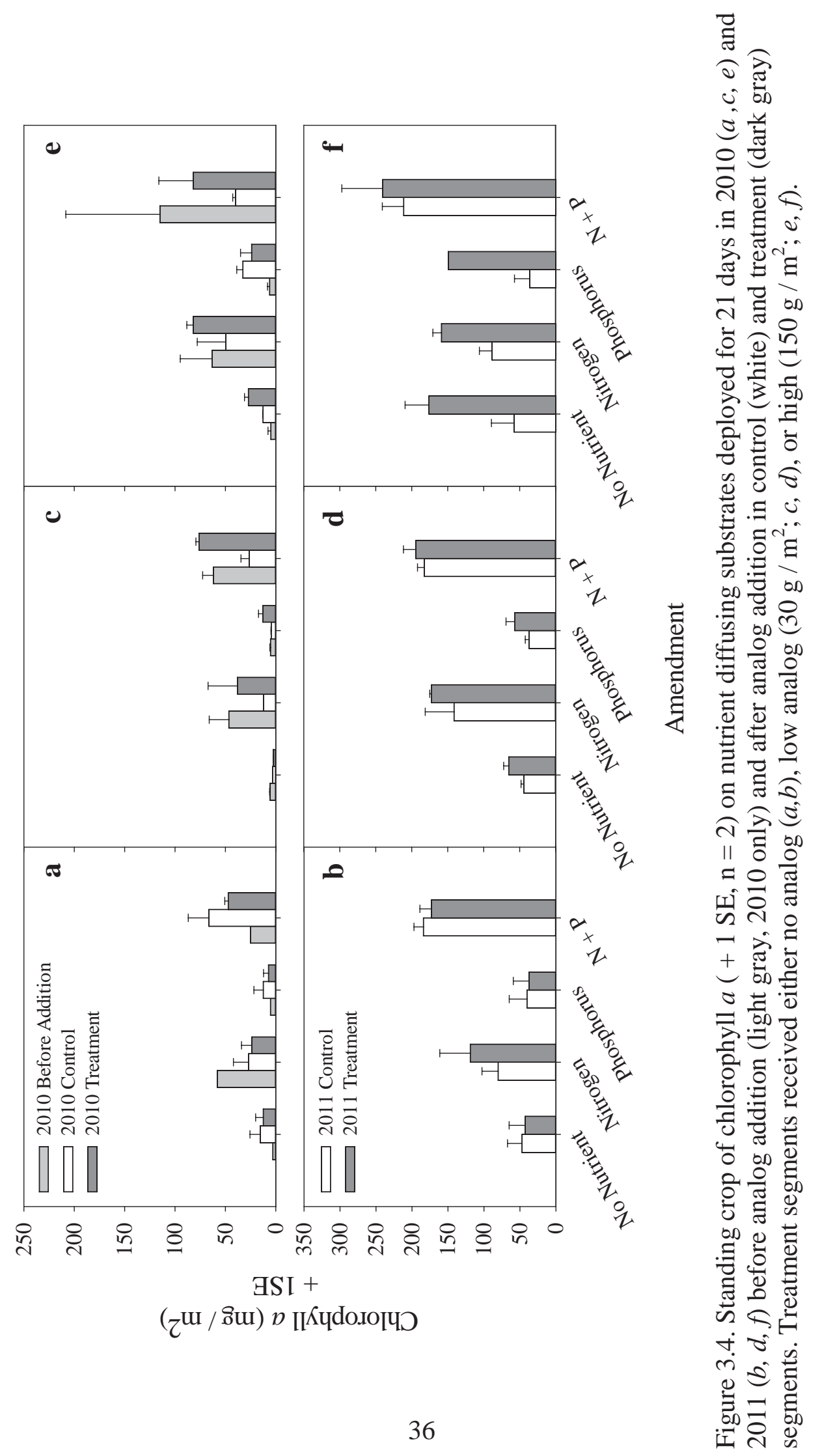




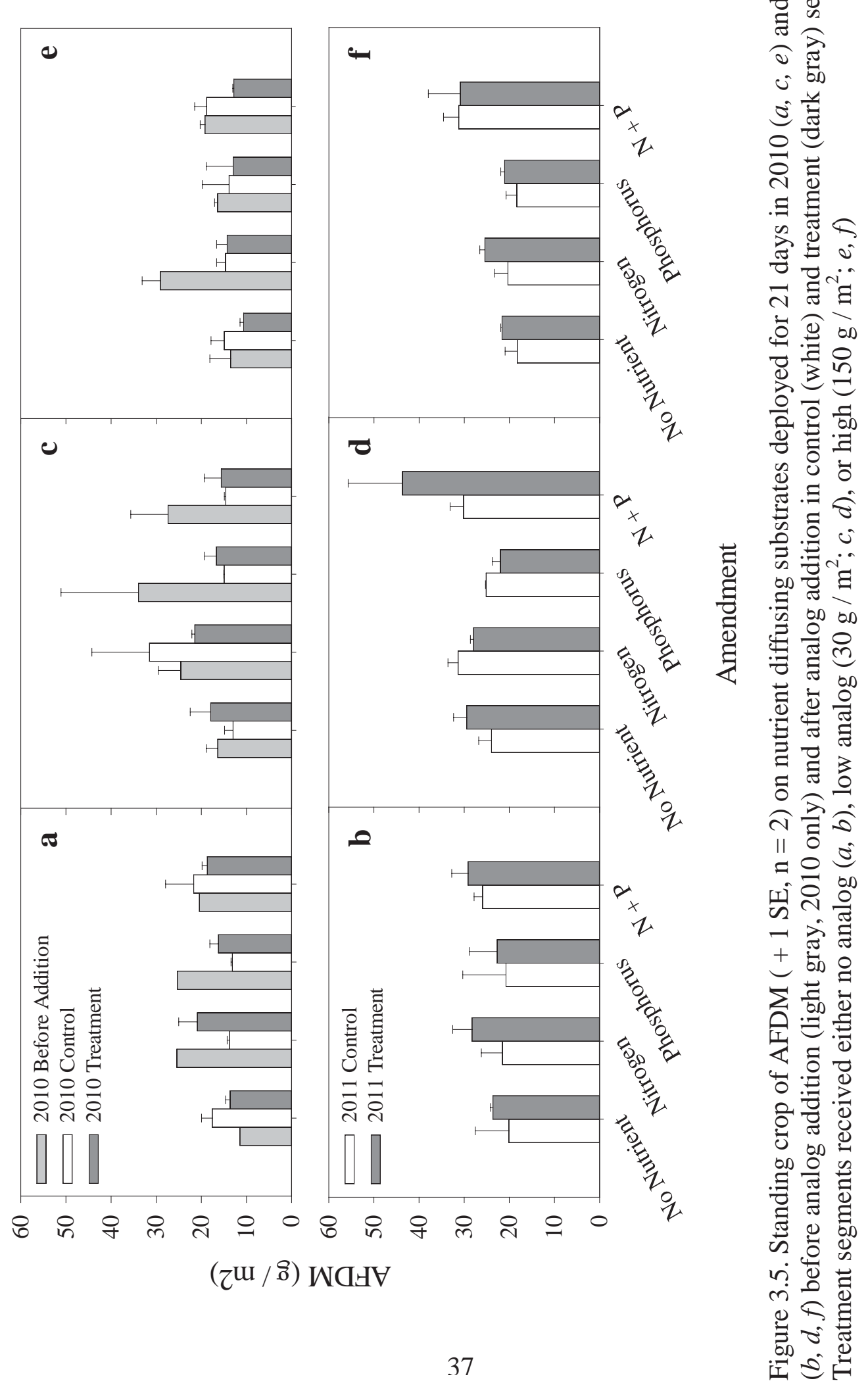




\subsection{Metabolism}

\subsubsection{Whole-stream metabolism}

Reaeration estimates from equations provided better metabolism estimates than the night-time regression method. Night time regression yielded $\mathrm{k}_{20}$ values two to threefold lower than the next lowest $\mathrm{k}_{20}$ (E7), and GPP estimates using these $\mathrm{k}_{20}$ values were only positive in the high analog treatment segment. Consequently, we focused our attention on metabolism parameters estimated with equation-based estimates of $\mathrm{k}_{20}$ (Table $3.5)$.

Gross primary productivity and ecosystem respiration were higher in the high analog treatment segment versus the control, but were similar in low analog treatment and control segment (Table 3.6). Daily gross primary productivity in our streams ranged from $1.63 \mathrm{mg} \mathrm{O}_{2} \mathrm{~m}^{-2} \mathrm{~d}^{-1}$ to $4.03 \mathrm{mg} \mathrm{O}_{2} \mathrm{~m}^{-2} \mathrm{~d}^{-1}$. Our high analog treatment had the highest GPP of the four segments. Mean daily GPP in the high analog treatment segment was $150 \%$ higher than the high analog control segment. Meanwhile, Mean daily GPP was approximately equal in the two segments of our low analog stream (Table 3.6).

Ecosystem respiration exceeded GPP in all of our study segments throughout September 2011, but followed a similar pattern of differences between segments. Mean daily ER ranged from 15.55 to $38.38 \mathrm{mg} \mathrm{O}_{2} \mathrm{~m}^{-2} \mathrm{~d}^{-1}$ across the four segments, and was $70 \%$ higher in the high analog treatment segment vs. the control segment (Table 3.6). Low analog control and treatment segments had higher ER than the high analog segments, but treatment differed from the control by only $16 \%$ in this stream. NEP was highly negative, ranging from -13.92 to $-36.26 \mathrm{mg} \mathrm{O}_{2} \mathrm{~m}^{-2} \mathrm{~d}^{-1}$, with the lowest estimates coming from the 
low analog segments. Finally, the ratio of production to respiration ranged from 0.05 in the low analog control segment to 0.17 in the high analog treatment segment.

Daily metabolism changed between the first nine (i.e., early September) and the last seven days of September (i.e., late September) (Figure 3.6 a-c). Sonde recalibration was concurrent with the change in metabolism and a sonde malfunction in the high analog treatment segment around September $10^{\text {th }}$ caused nine day gap in metabolism estimates for this segment. This sonde was fixed, calibrated and redeployed at the same time as the sondes in the other segments. Daily GPP declined by $20-30 \%$ in high analog segments, with the greater decrease occurring in treatment segment. Low analog segments showed a steeper decline in GPP than high analog segments, with late September GPP being $41 \%$ and $85 \%$ lower in the treatment and control segments, respectively. Daily GPP appeared to converge around September $19^{\text {th }}, 2011$ at $1.5 \mathrm{mgO}_{2}$ $\mathrm{m}^{-2} \mathrm{~d}^{-1}$ in high analog control, low analog treatment and low analog control segments, whereas the high analog treatment segment fell to between 3.03 to $3.37 \mathrm{mgO}_{2} \mathrm{~m}^{-2} \mathrm{~d}^{-1}$. Daily ER decreased between early and late September in the high analog treatment segment by $24 \%$ and increased in the high analog control, low analog treatment, and low analog control segments by $11 \%, 5 \%$, and $20 \%$ respectively. 
Table 3.5

Reaeration coefficients $\left(\mathrm{k}_{20}\right)$ of control and treatment segments of Cape Horn Creek (high analog) and Basin Creek (low analog) during September 2011.

\begin{tabular}{lrrrr}
\hline \hline \multirow{2}{*}{ Method } & \multicolumn{4}{l}{ Low Analog } \\
\cline { 2 - 5 } Median NT & Treatment $\left(\mathrm{h}^{-1}\right)$ & Control $\left(\mathrm{h}^{-1}\right)$ & Treatment $\left(\mathrm{h}^{-1}\right)$ & Control $\left(\mathrm{h}^{-1}\right)$ \\
\hline E1 & 0.60 & 0.32 & 0.62 & 0.47 \\
E2 & 2.40 & 1.55 & 4.35 & 4.57 \\
E3 & 2.25 & 1.50 & 4.22 & 4.32 \\
E4 & 2.09 & 1.41 & 3.88 & 3.93 \\
E5 & 1.91 & 1.28 & 3.73 & 3.82 \\
E6 & 2.16 & 1.46 & 3.99 & 4.03 \\
E7 & 2.26 & 1.51 & 4.00 & 4.37 \\
E8 & 1.15 & 0.91 & 1.56 & 1.69 \\
\hline
\end{tabular}

Table 3.6

Mean daily GPP, ER, NEP, and GPP : ER in control and treatment segments of high analog and low analog streams estimated using the median $\mathrm{k}_{20}$ calculated from E1-E8.

\begin{tabular}{|c|c|c|c|c|c|}
\hline $\begin{array}{l}\text { Analog } \\
\text { Level }\end{array}$ & Segment & $\begin{array}{l}\mathrm{GPP} \\
\left(\mathrm{mg} \mathrm{O}_{2} \mathrm{~m}^{-2} \mathrm{~d}^{-1}\right) \\
\pm 1 \mathrm{SD}\end{array}$ & $\begin{array}{l}\mathrm{ER} \\
\left(\mathrm{mg} \mathrm{O}_{2} \mathrm{~m}^{-2} \mathrm{~d}^{-1}\right) \\
\pm 1 \mathrm{SD}\end{array}$ & $\begin{array}{l}\mathrm{NEP} \\
\left(\mathrm{mg} \mathrm{O}_{2} \mathrm{~m}^{-2} \mathrm{~d}^{-1}\right) \\
\pm 1 \mathrm{SD}\end{array}$ & $\mathrm{P}: \mathrm{R}$ \\
\hline High & Treatment & $4.03 \pm 0.85$ & $24.12 \pm 3.44$ & $-20.05 \pm 2.63$ & 0.17 \\
\hline Analog & Control & $1.63 \pm 0.18$ & $15.55 \pm 0.90$ & $-13.92 \pm 1.01$ & 0.10 \\
\hline Low & Treatment & $2.21 \pm 0.59$ & $32.35 \pm 0.98$ & $-30.10 \pm 1.44$ & 0.07 \\
\hline Analog & Control & $2.06 \pm 0.60$ & $38.38 \pm 4.09$ & $-36.28 \pm 4.52$ & 0.05 \\
\hline
\end{tabular}



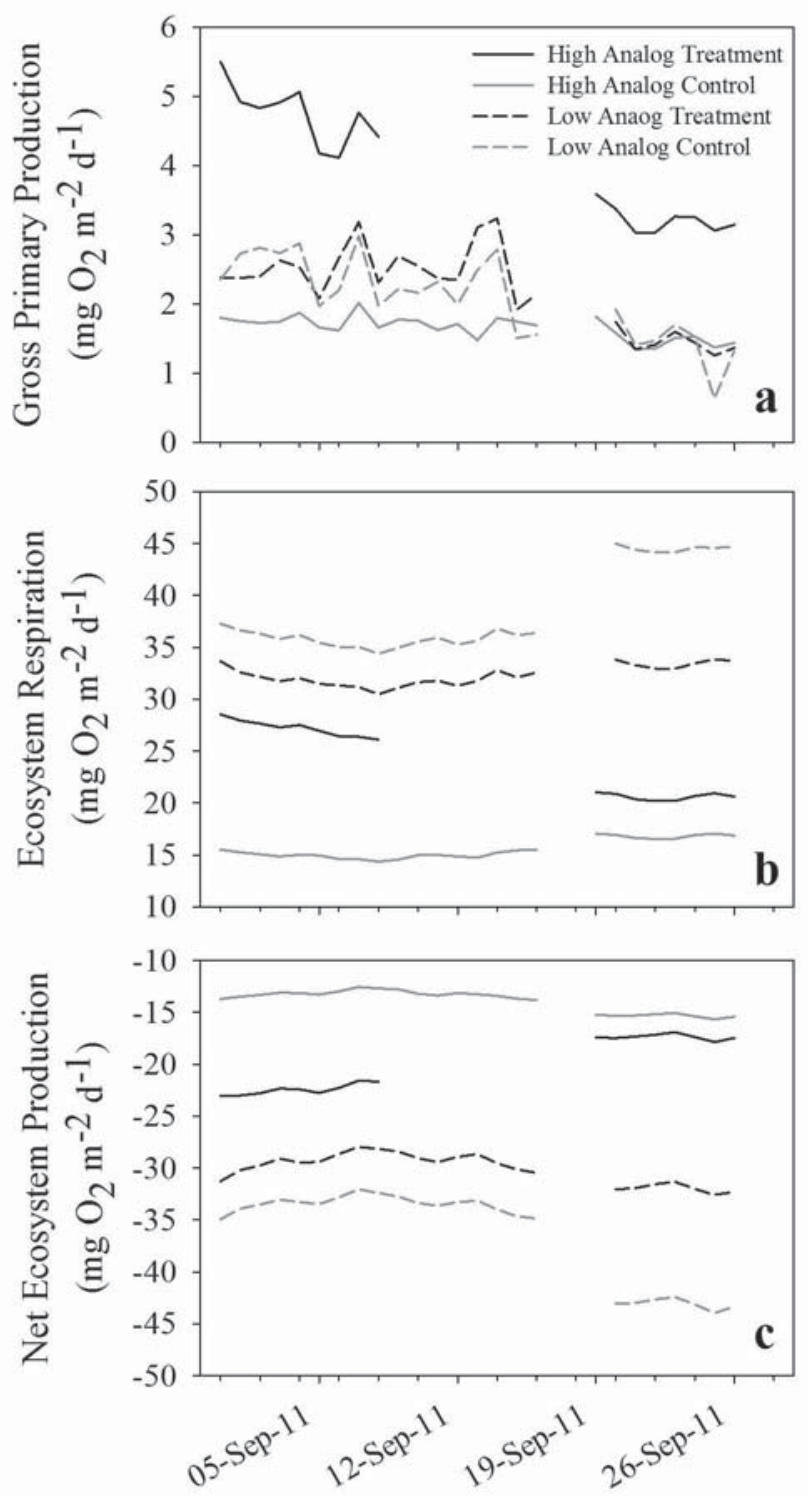

Julian Date

Figure 3.6. Time series of gross primary productivity $(a)$, ecosystem respiration $(b)$, net ecosystem production $(c)$ in control (dark gray) and treatment (black) segments of Basin Creek (low analog; dashed lines) and Cape Horn Creek (high analog; solid lines) near Stanley, ID between 31 Aug 2011 and 26 Sept 2011. All values were calculated from continuous diel oxygen records from YSI $6920 \mathrm{~V} 2$ water quality sondes using the median reaeration coefficient $\left(\mathrm{k}_{20}\right)$ predicted with E1-E8. 


\subsubsection{Benthic Metabolism}

Benthic respiration in light-dark recirculating chambers was three-fold higher in treatment vs. control segments under high analog but did not differ under low analog or no analog levels (Table 3.7, Figure 3.7a). NCP did not respond significantly to any analog level (Table 3.7, Figure 3.7b). We used the mean NCP and R values shown in Figure 3.6a \& b to calculate GPP in each segment; because light and dark chambers are not directly paired, GPP values have no replication within analog levels and do not have error bars. It appears that GPP was four-fold higher under high SCA additions, but was not different under no or low analog additions (Figure 3.7c).

Table 3.7

Results of one-tailed $t$-tests on NCP (light chambers) and R (dark chambers) in control and treatment segments under three different analog levels. $n=3$ for all bars. $\alpha$ was Bonferroni corrected for multiple t-tests and $p=0.017$ is indicated with an $(*)$.

\begin{tabular}{ccccc}
\hline \hline & \multicolumn{2}{c}{ NCP } & \multicolumn{2}{c}{$\mathrm{R}$} \\
\cline { 2 - 5 } Analog & \multicolumn{3}{c}{ T-statistic } & $p$ \\
\hline Level & T-statistic & $p$ & 2.27 & 0.946 \\
No Analog & 1.63 & 0.100 & 1.79 & 0.108 \\
Low & 0.26 & 0.590 & 5.33 & $* 0.017$ \\
High & 2.34 & 0.051 & & \\
\hline
\end{tabular}



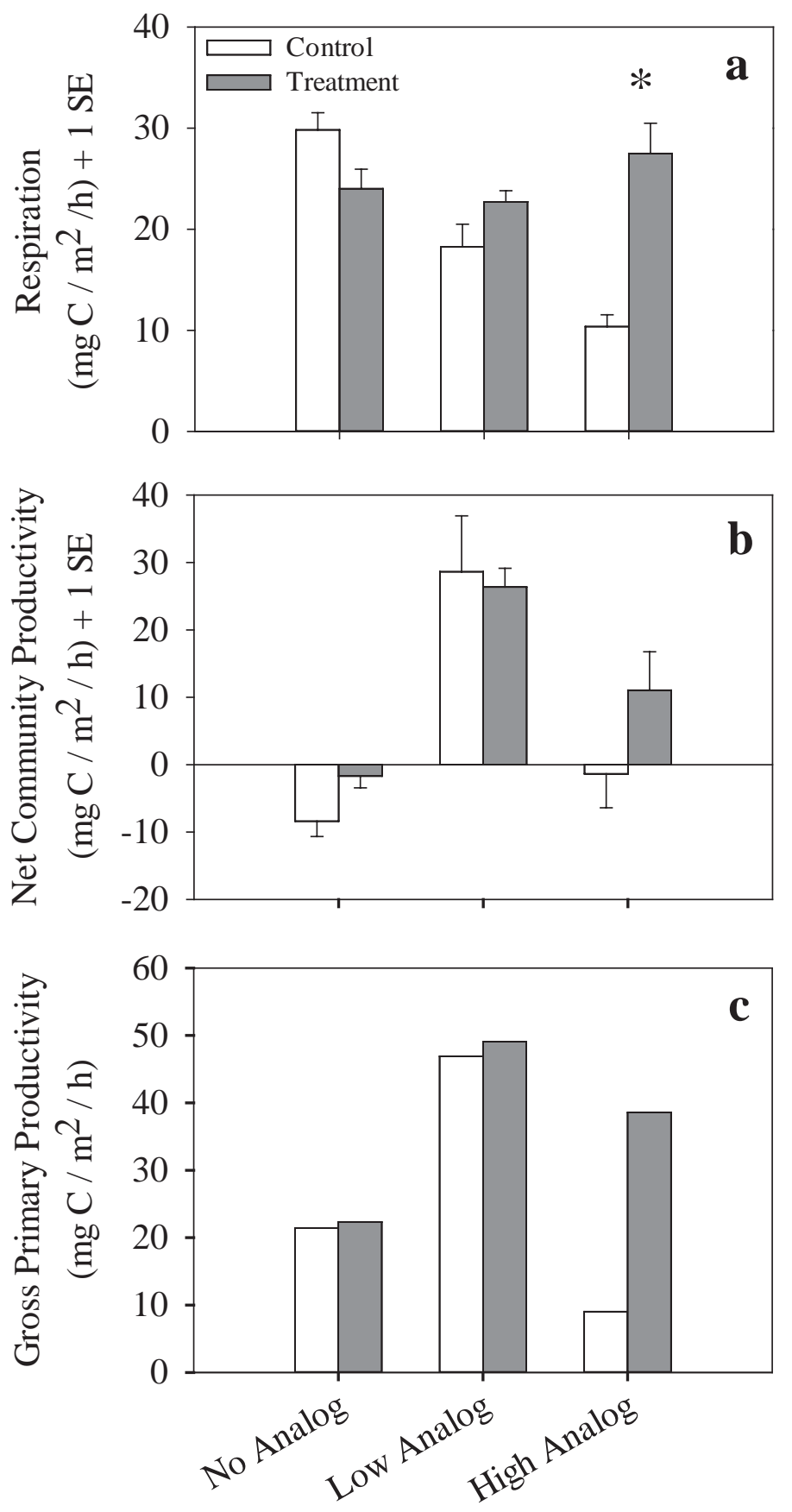

Figure 3.7. Respiration (a), net community productivity (b), and gross primary productivity (c) of benthic biofilms measured in light/dark re-circulating chambers. $n=3$ for each bar. (*) indicates statistically significant difference. 


\section{DISCUSSION}

Our objective was to assess changes in three biofilm response metrics to the addition of salmon nutrients in Idaho streams; biofilm standing crop, nutrient limitation and metabolism. We were specifically interested in the strength of the biofilm pathway as a vector for the movement of salmon nutrients into the stream food web, which would require an increase in biofilm production. We added salmon carcass analog in the middle of August to mimic the timing of peak returns of Chinook salmon to the upper Salmon River. Both analog addition and biofilm sampling occurred at a larger extent $(3 \mathrm{~km})$ than previous studies (4-1000 m; Janetski et al. 2009). We found no effect of analog on biofilm standing crop or nutrient limitation, but analog addition may have altered benthic and whole-stream metabolism. Ecosystem respiration and gross primary production responded strongly to high analog addition in one stream. Whole-stream metabolism estimates suggest that high analog addition shifted the stream ecosystem towards greater heterotrophy whereas benthic metabolism measurements suggest that GPP and ER responses were balanced.

In the following, we will first discuss issues associated with our experimental design and the limitations of our whole stream metabolism estimates. We will then compare our results to biofilm responses to other artificial salmon nutrient additions and natural salmon spawning events before we discuss factors that constrain benthic biofilm biomass accrual and evaluate alternative fates of salmon carbon and nutrients in our streams. Finally, we will discuss the implications of our results for salmon nutrient 
mitigation efforts and possible future avenues for studying the role of salmon in ecosystem processes.

\subsection{Experimental design}

Our study was part of a larger effort to examine food web responses to the addition of salmon carcass analog and an extension of previous research (see Kohler et al. 2008; Kohler and Taki 2010; Kohler et al. 2012). In 2010, we sampled biofilm standing crop at the same sites and according to the same stratified design as co-occurring macroinvertebrate sampling. The lack of detectable differences in 2010 biofilm standing crop could be attributed to inadequate within segment sampling because our original sampling design did not account for the great spatial heterogeneity of biofilm standing crop, which varies substantially at scales ranging from individual substrates to kilometers (Stevenson 1997). Equipment failure during chlorophyll analysis caused the loss of all 2010 low analog treatment standing crop samples, which may have also contributed to lowering our statistical power. In 2011, we greatly increased our power to detect differences by changing our sampling design and solving our equipment issues. The change in sampling design between years did not alter our results; we did not find differences in biofilm standing crop in either 2010 or 2011.

A cautious and conservative interpretation of our whole stream metabolism estimates is warranted. First, we were limited in the number of streams in which we could estimate benthic and whole-stream metabolism, which resulted in low replication of our results. Second, our study streams were wide, shallow and turbulent, and these morphologic characteristics made it difficult to estimate gas exchange with the 
atmosphere with direct gas evasion. Gas evasion provides the most precise estimates of reaeration coefficients (k; Marzolf et al. 1994; Young and Huryn 1998; Young and Huryn 1999). Young and Huryn (1999) used sulfur hexafluoride $\left(\mathrm{SF}_{6}\right)$ gas evasion successfully in streams with wetted width to depth ratios between 10 and 21.3. The width to depth ratio of our high analog control, high analog treatment, low analog control, and low analog treatment segments was $35.6,40.3,31.0$, and 51.9, respectively. The larger width to depth ratios made it difficult to mix $\mathrm{SF}_{6}$ evenly across the stream, which precluded the use of this technique in our streams. To overcome this problem, we employed multiple mathematical methods to estimate reaeration including the night-time regression method (Hornberger and Kelly 1975), fitted empirical equations (Melching and Flores 1999; Raymond et al. 2012), and a classic model (Tsivoglou and Neal 1976) suggested by Bott (2006). Conclusions about stream metabolism utilizing reaeration coefficients calculated with generalized equations in streams for which the equations are ill suited should be viewed cautiously (Wallin et al. 2011; Raymond et al. 2012) because GPP and ER are highly sensitive to small differences in reaeration estimates. Estimates of $k_{20}$ from the night-time regression method showed little agreement with generalized equations, and are consistent with Aristegi et al. (2009) who found that agreement between methods was especially low in shallow streams. Most comparisons of reaeration coefficients from gas evasion to mathematical methods find that many empirical equations underestimate gas exchange in high gradient, turbulent streams. As a result of an underestimated $\mathrm{k}_{20}$, we likely underestimated GPP and overestimated ER in our study segments (Young and Huryn 1999). 


\subsection{Biofilm responses to salmon nutrients}

Biofilm responses to salmon nutrients vary by region, salmon nutrient load, and whether salmon nutrients are added artificially or via natural spawning events (Janetski et al. 2009). In some previous studies live salmon, carcass presence, and carcass analog addition had strong bottom up effects on biofilm chlorophyll $a$ and AFDM in natural streams (Chaloner et al. 2007; Kohler et al. 2008; Ruegg et al. 2012) and artificial stream channels (Wipfli et al. 1998; Wipfli et al. 1999; Kiernan et al. 2010; Albers and Petticrew 2012). In contrast, other studies have found that naturally spawning salmon reduced biofilm standing crop in streams with small sediments (Holtgrieve et al. 2010; Verspoor et al. 2010), or that addition of carcasses to natural streams and artificial stream channels did not alter biofilm standing crop (Minshall et al. 1991; Ambrose et al. 2004; Claeson et al. 2006; Cram et al. 2011). Overall, artificial additions lead to higher biofilm standing stocks than live salmon, presumably due to the tendency for artificial additions to exceed the nutrient loads from natural salmon runs and lack the disturbance of substrates associated with natural spawners (Janetski et al. 2009).

Assessments of nutrient limitation in the context of salmon nutrients have also had mixed results. Our nutrient limitation results are consistent with other studies in central Idaho streams that documented nitrogen limitation or $\mathrm{N}$ and $\mathrm{P}$ co-limitation of benthic biofilms (Marcarelli and Wurtsbaugh 2007; Kohler et al. 2008; Sanderson et al. 2009). Similar to studies where artificial salmon nutrient additions failed to alter patterns of biofilm nutrient limitation in California and Idaho streams (Ambrose et al. 2004; Kohler et al. 2008), biofilms in our current study remained N-limited after analog addition. In contrast, spawning salmon in Alaska alleviated biofilm nutrient limitation 
(Ruegg et al. 2011; Tiegs et al. 2011). Ruegg et al. (2011) found that the presence of naturally spawning salmon alleviated autotroph nutrient limitation in 6 of 7 study streams on Prince Wales Island, Alaska. Similarly on Prince Wales Island, Tiegs et al. (2011) found that biofilms were not nutrient limited when live salmon and carcasses were present, but biofilms returned to pre-spawn nutrient limitation shortly after the completion of spawning but while carcasses were still present. These studies suggest that live salmon have greater impact on biofilm nutrient limitation than do carcasses because of spawning disturbance and excretion of metabolic wastes (Tiegs et al. 2011). It is plausible that the inconsistency between our nutrient limitation results and those in Alaskan streams may be due to the inability of salmon carcass analog to mimic the nutrient enrichment and disturbance properties of natural spawning salmon runs. It is important to note, however, that the species of nitrogen used in NDS deployed in our study and that of Kohler et al. (2008) differed from the nitrogen amendment used in the two Alaskan studies above. We used sodium nitrate in our bioassays $\left(\mathrm{NaNO}_{3}\right)$ whereas Ruegg et al. (2011) and Tiegs et al. (2011) used ammonium chloride $\left(\mathrm{NH}_{4} \mathrm{Cl}\right)$.

Increased ammonium supply from analog addition may have caused increased chlorophyll $a$ standing crop on NDS deployed in high analog streams. In our study, stream water ammonium concentrations increased $40 \%$ and $250 \%$ in our two high analog treatment segments (Kohler, unpublished data). In other studies, similar additions of pasteurized carcasses and salmon carcass analog resulted in elevated stream water ammonium concentrations, but did not alter nitrate levels (Claeson et al. 2006; Kiernan et al. 2010; Wipfli et al. 2010). Natural salmon runs are also associated with strongly elevated ammonium concentrations, yet nitrate concentrations typically remained 
unchanged (Mitchell and Lamberti 2005; Chaloner et al. 2007) or increase just after the initial onset of spawning (Tiegs et al. 2011). Additionally, nitrogen limitation of AFDM on NDS in our study was more frequent in treatment segments than control segments suggesting that total biofilm community biomass shifted from being limited by carbon or to being limited by nitrogen. We used inorganic substrates in our bioassays, and thus heterotrophic microbial populations were supported by algal carbon and used algal cells as their primary substrate for colonization (Rier and Stevenson 2002). Because AFDM is total community biomass (i.e., autotrophs + heterotrophs), this result suggests that heterotrophic biomass on NDS in control segments may have been limited by suitable substrate for colonization rather than nitrogen or phosphorous. Higher NDS algal densities in treatment segments may have alleviated organic substrate limitation.

We expected analog addition to positively influence rates of primary production by increasing nitrogen and phosphorus supply. Both benthic and whole-stream metabolism estimates from this study supported this hypothesis. Not surprisingly, GPP was very low in our study streams due to the highly oligotrophic conditions common in central Idaho streams (Sanderson et al. 2009). Benthic GPP in our study was comparable to estimates obtained in tributaries of the Middle Fork of the Salmon River (Davis 1995). Even after analog addition, whole-stream GPP was an order of magnitude lower than GPP of most other open-canopy stream systems and comparable to GPP in heavily shaded headwater streams (Mulholland et al. 2001). Despite low GPP estimates in our streams, the ratio of production to respiration in all segments fell within the range of GPP : ER commonly observed in streams, albeit at the lower end of that range (Marcarelli et al. 2011). Studies assessing changes in benthic and whole-stream metabolism to 
spawning salmon and nutrients are limited, but suggest that GPP declines when salmon spawn, and ER increases with the post-spawning disturbance influx of nutrients (Holtgrieve and Schindler 2011).

The increase in labile organic carbon may have caused changes in ecosystem respiration, which supports the potential importance of salmon nutrient subsidies to heterotrophic processes. We found a $70 \%$ increase of ER in our high analog treatment versus control segments during the 10 days of September, and benthic respiration measured with dark chambers increased by $165 \%$. Holtgrieve and Schindler (2011) found a similar increase in ER in Alaskan sockeye streams containing a peak salmon abundance of $>0.6$ live salmon per square meter and suggested four mechanisms by which salmon can increase ER: (1) creating greater access to surface area for colonization and growth of heterotrophic microbial populations through streambed disturbance; (2) increasing nutrient concentrations; (3) releasing labile carbon; and (4) directly consuming $\mathrm{O}_{2}$. Mechanisms (1) and (4) are not applicable to our streams. Sockeye salmon density in Holtgrieve and Schindler (2011) was associated with a nutrient and carbon load approximately equivalent to our high analog level but streambed disturbance by salmon in our study was negligible relative to streams in Alaskan sockeye streams; redd counts in our high analog stream suggests a minimum live salmon density of 0.002 salmon per square meter. Additionally, changes in ecosystem metabolism with increased input of labile allochthonous carbon observed in our study and by Holtgrieve and Schindler (2011) are not restricted to salmon-bearing ecosystems. Bernhardt and Likens (2002) found that the addition of dissolved organic carbon (DOC) resulted in elevated ER, and increased carbon supply stimulated microbial nutrient demand, shortened nutrient uptake 
lengths, and caused a decrease in stream water nitrate concentrations. The similarity between the response of ER to live salmon, salmon carcass analog, and artificial DOC indicates that mechanisms (2) and (3) may be the primary mechanisms by which salmon influence ecosystem respiration.

We observed changes in whole-stream GPP and ER during the third week of September. Decreasing GPP was common to all segments, but the segments exhibited opposite responses in ER. The high analog treatment segment was the only segment to exhibit a decrease in ER whereas ER increased in the other three segments. It is doubtful that fluctuations in stream discharge, velocity, slope, or other physical variables related to reaeration coefficient of treatment segments would have produced the observed change because streams in central Idaho are at baseflow from July onward. Stream temperature can influence ER and GPP (Allen et al. 2005; Demars et al. 2011) and explain up to 50\% of seasonal variation in GPP and ER (Uehlinger 2006). Peak day-time water temperature in our streams declined approximately $1^{\circ} \mathrm{C}$ during the month of September; however, falling temperature fails to explain changes in GPP and ER in treatment segments because stream metabolism in control segments did not decrease with this change in temperature. Re-calibration of dissolved oxygen sensors at the same time as changes in stream metabolism and may have contributed to part of this change. Alternatively, decreasing GPP in all segments may be explained by algal senescence, the increased ER in low analog and control segments to the input of leaves during the rapid senescence of riparian vegetation that occurred at this time (Ebel, personal observation), and the decreasing ER in the high analog segment to a declining effect of analog. 


\subsection{Constraints of biofilm standing crop}

Like all biota, the growth and reproduction of microbes within benthic biofilms is constrained by a suite of abiotic and biotic environmental pressures that are largely independent of resource availability. Here, we focus our discussion on light availability, macroinvertebrate grazing pressure, and biofilm age as three possible factors that may explain the lack of differences in biofilm standing crop between treatment and control segments despite increases in benthic and whole-stream GPP and ER.

Light intensity synergistically interacts with nutrient availability to control algal standing crop and gross primary productivity (Hill et al. 2011), thus light intensity has been discussed as a major constraint on biofilm response to salmon nutrients (Cedarholm et al. 1999). Photosynthesis and algal biomass is positively associated with light intensity, with higher GPP and chlorophyll $a$ concentrations occurring in open canopy streams with abundant light (McIntire and Phinney 1965; Mullholland et al. 2001; Rier and Stevenson 2002; Kiffney et al. 2004). Open canopy streams are also associated with a greater occurrence of biofilm nutrient limitation (Lowe et al. 1986) because algae are no longer constrained by light availability. In our study, we saw a significant positive relationship between canopy cover and chlorophyll $a$ on rocks. This result is in direct contrast with what is observed in many other studies and may be explained by differences in canopy cover and chlorophyll $a$ between geographic areas (shown in Figure 2.2). Within basins, segments showed no significant relationships between canopy cover and chlorophyll $a$.

Macroinvertebrate grazing may exert a strong negative top-down force on biofilm standing crop and obscure increases in biofilm standing crop associated with salmon nutrients. Many studies have demonstrated positive associations between artificial 
additions of salmon nutrients and the abundance and density of macroinvertebrates that feed on algae (i.e., grazers) (Wipfli et al. 1998; Wipfli et al. 1999; Claeson et al. 2006, Kohler et al. 2008; Kohler and Taki 2010; Kohler et al. 2012). Bottom-up effects of inorganic nutrient enrichment on macroinvertebrate production is commonly observed in streams (Peterson et al. 1985; Hart and Robinson 1990; Cross et al. 2006) as is top-down control of biofilm biomass (Lamberti and Resh 1983; Lamberti et al. 1989, Peterson et al. 1993; Hillebrand and Kahlert 2001). During a 5 year nutrient enrichment of a tundra stream, Peterson et al. (1993) observed an initial increase in chlorophyll $a$ causing a positive numerical response of grazing macroinvertebrates, which in turn, decreased algal standing crop during the final years of the enrichment. Similarly, if analog addition had bottom up effects on grazer populations, we would not expect to see the full extent of grazing-inhibited biofilm standing crop until the second year of our study. Because we did not observe standing crop differences in either year, we cannot attribute the lack of analog-induced standing crop responses to grazing; however, our power to detect differences in 2010 may have hidden a small increases in biofilm standing crop with analog addition, thus we cannot reject the grazing-constraint hypothesis. To date, few published studies have documented changes in macroinvertebrate density and biofilm standing crop to multiple years of artificial salmon nutrient enrichment. Yet, multi-year studies of grazer-biofilm-salmon nutrient are critical to determining the movement of salmon nutrients into the foodweb via the biofilm pathway and should be vigorously pursued.

Disturbance can determine changes in biofilm production with nutrient enrichment by influencing spatial and temporal patterns in biofilm development (Biggs et 
al. 1999). Biofilms mature rapidly following disturbances (i.e., scouring, grazing) and can obtain maximum biomass for a given stream flow velocity in 30-50 days (Battin et al. 2003; Besemer et al. 2007). In our streams, scouring of the entire streambed during spring snowmelt constitutes the largest disturbance of any given year in both magnitude and extent (Hall et al. 2009) and provides a starting point for biofilm succession. We added salmon carcass analog to treatment segments 61 and 53 days after peak run-off in 2010 and 2011, respectively, which suggests that biofilms in our streams may have reached maturity. Mature, or fully developed biofilms tend to have maximized efficiency (i.e., yield of biomass per unit resource; Kreft 2004) and rely on the internal recycling of nutrients and carbon to support energy requirements (Mulholland et al. 1994). Internal recycling of nutrients is important because the rate of diffusion between the overlying water and microbial cells decreases as biofilm thicken with age (Battin et al. 2003). Nutrient enrichment may lead to higher algal productivity, but rather than incorporate the new carbon into biomass mature biofilms may respond by increasing the release rate of autochthonous DOC (Ziegler and Lyon 2010). In contrast, less developed biofilms tend to maximize the production of new biomass (Kreft 2004) by exhibiting high DOC uptake rates and incorporating more carbon into new biomass (Augspurger et al. 2008). As a result, less developed biofilms respond more strongly to nutrient enrichment than do older biofilms (Sobczak 1996), which is manifested in higher biofilm productivities on frequently disturbed substrates (Cardinale et al. 2005). The difference between the productivity of less developed biofilms vs. mature biofilms may explain why biofilm standing crop was higher after analog addition on unamended NDS in 2011 and on unglazed tiles in 2003 (Kohler et al. 2008), when biofilms on natural substrates in the 
same streams did not respond to analog. The hypothesis that disturbance and nutrient enrichment may have a synergistic rather than antagonistic effect on annual biofilm production is underrepresented in salmon-ecosystem and nutrient mitigation literature, but should be considered.

\subsection{Alternative fates of salmon carcass analog}

The discrepancy between standing crop and metabolism responses suggests that a portion of the carbon and nutrients from salmon carcass analog are assimilated by benthic biofilms in our streams, but are not being accumulated in biofilm standing crop. This raises an important question: Where did the organic material in salmon carcass analog ultimately go?

The positive association of chlorophyll $a$ with canopy cover combined with the nearly significant negative relationship between discharge and biofilm chlorophyll $a$ is perplexing. Chlorophyll $a$ is expected to decrease with increasing canopy cover and decreasing discharge (Vannote et al. 1980). We suspect that this result is due to the interaction between analog addition and the geomorphological characteristics of our streams. Streams with broad, open floodplains may have a larger transient storage zone relative to total stream cross sectional area, thus have a greater capacity to store nutrients in the hyporheic zone (D'Angelo et al. 1993). The larger streams in our study occurred in the Salmon basin and nutrients may have moved into the hyporheic zone rather than being taken up by streambed biofilms. Storage and transformation of nutrients and carbon in the hyporheic zone is another possible fate of salmon carcass analog in our streams as evidenced by the difference between benthic and whole-stream metabolism. Elevated 
benthic respiration in the high analog treatment segment was not accompanied by increased NCP indicating that benthic GPP was respired. Meanwhile, whole-stream ER was vastly greater than whole-stream GPP indicating that a substantial portion of ER can be attributed the metabolic activity of hyporheic microbes (Mulholland et al. 1997; Fellows et al. 2001; Hall and Tank 2005). Hyporheic storage may constitute a sizeable fraction of a stream nitrogen budget and exceed uptake and storage in benthic biota (Triska et al. 1989). Conversely, the hyporheic zone may be a nitrogen sink because adequate carbon availability and anoxic conditions can permit denitrification (Pinay et al. 2003; Schade et al. 2001).

The hyporheic zone and streambed may have the capacity to store salmon nutrients over the winter before re-releasing the nutrients the following spring ( $\mathrm{O}$ 'Keefe and Edwards 2002). Recent work on the transport and storage of salmon nutrients suggests flocculation (i.e., the physical, biological, or chemical joining of inorganic and organic particles) can facilitate the transport of salmon nutrients and carbon into the streambed (Rex and Petticrew 2008) where it is retained longer than in surface or interstitial waters (Rex and Petticrew 2010). In our study, movement of analog particulates into the hyporheic zone may have stimulated microbial activity. Because hyporheic exchange is a characteristic of many present and historic salmon spawning streams, the role of the hyporheic zone in storing or removing salmon nutrients from the stream may impact decisions regarding the feasibility of effective nutrient mitigation and conclusions about the importance of salmon nutrient enrichment to stream ecosystem processes. 


\subsection{Future of the 'biofilm pathway' paradigm}

Elucidating the ultimate fate of salmon nutrients is an important step towards the effective and efficient restoration of Pacific salmon populations in the contiguous United States and should be an objective of research on the role of salmon in stream ecosystem processes. In our study, salmon carcass analog had strong effects on respiration and caused higher rates of primary production; however it is unclear whether the increase in primary and secondary microbial productivity will directly stimulate higher trophic levels. Benthic and whole-stream metabolism estimates had a profound effect on our interpretation of our nutrient limitation and standing crop results by highlighting the potential processing and storage of salmon nutrients in the hyporheic zone of our study streams. Additionally, salmon nutrient enrichment during late summer may influence how biofilms respond to changing seasons, with consequences for food web productivity prior to snow-melt scouring in the spring. We suggest that future research on salmon nutrient mitigation utilize measures of ecosystem metabolism, explore the role of the hyporheic zone in storing or removing nutrients and carbon, and consider the physiological implications of organic nutrient supply for the persistence of biofilms through the winter and following spring.

Our study suggests that high levels of salmon carcass analog addition may incite a biofilm response; however, documenting a simple organismal response does not mean that the goals of nutrient mitigation have been achieved. The primary question of mitigation research should shift from "Do stream ecosystems respond to salmon nutrient additions?" to "Where are the added carbon and nutrients going?" This second question can be answered with carbon and nitrogen budgets of target watersheds that identify 
whether added nutrients are stored within relevant ecosystem compartments (e.g., biota, particulate organic matter, hyporheic zone, terrestrial vegetation) or exported via respiration, denitrification, or flushing downstream. As salmon populations creep ever closer to complete collapse, it is essential that effort allocated to maintain healthy salmon populations be spent wisely. How much of the money allocated to nutrient mitigation is moving to the ocean as migrating salmon smolts and how much of that investment returns as spawning adults? Alternatively, how much of that money is flushed downstream to be stored and processed behind the same hydroelectric dams that are responsible for the decline of Idaho's salmon in the first place? These questions must be answered for nutrient additions to be accepted as a viable way to lessen the gravity of the socioindustrial assault on the Pacific salmon populations of the contiguous United States. 


\section{References}

Albers SJ and Petticrew EL. 2012. Ecosystem response to a salmon disturbance regime: Implications for downstream nutrient fluxes in aquatic systems. Limnology and Oceanography 57:113-123.

Allen AP, Gillooly JF, and Brown JH. 2005. Linking the global carbon cycle to individual metabolism. Functional Ecology 19:202-213.

Ambrose HE, Wilzbach MA, and Cummins KW. 2004. Periphyton response to increased light and salmon carcass introduction in northern California streams. Journal of the North American Benthological Society 23:701-712.

American Public Health Association. 2005. Standard methods for the examination of water and waste water. American Public Health Association, Washington, DC.

Aristegi L, Izagirre O, and Elosegi A. 2009. Comparison of several methods to calculate reaeration in streams, and their effects on estimation of metabolism. Hydrobiologia 635:113-124.

Augspurger C, Gleixner G, Kramer C and Kusel K. 2008. Tracking carbon flow in 2week-old and 6-week old stream biofilm food web. Limnology and Oceanography 53:642-650.

Augspurger C and Kusel K. 2010. Flow velocity and primary production influences carbon utilization in nascent epilithic stream biofilms. Aquatic Sciences 72:237-243.

Battin TJ, Kaplan LA, Newbold JD, Cheng X, and Hansen C. 2003. Applied and Environmental Microbiology 69:5443-5452.

Bergey EA and Getty GM. 2006. A review of methods for measuring the surface area of stream substrates. Hydrobiologia 556:7-16.

Bernhardt ES and Likens GE. 2002. Dissolved organic carbon enrichment alters nitrogen dynamics in a forest stream. Ecology 83:1689-1700.

Besemer K, Singer G, Limberger R, Chlup A, Hochedlinger G, Hodl I, Baranyi C, and Battin TJ. 2007. Biophysical controls on community succession in stream biofilms. Applied and Environmental Microbiology 73:4966-4974.

Biggs BJF, Smith RA, and Duncan MJ. 1999. Velocity and sediment disturbance of periphyton in headwater streams: biomass and metabolism. Journal of the North American Benthological Society 18:222-241. 
Bilby RE, Fransen BR, and Bisson PA. 1996. Incorporation of nitrogen and carbon from spawning coho salmon into the trophic system of small streams: evidence from stable isotopes. Canadian Journal of Fisheries and Aquatic Sciences 53:164-173.

Bilby RE, Fransen BR, Walter JK, Cederholm J, and Scarlett WJ. 2001. Preliminary evaluation of the use of nitrogen stable isotope ratios to establish escapement levels for Pacific salmon. Fisheries 26:6-14.

Bott TL. Primary productivity and community respiration. In: Hauer FR and Lamberti GA. 2006. Methods in Stream Ecology, $2^{\text {nd }}$ ed. Elvsevier, Inc. Burlington, Massachusetts, USA. pp. 663-690.

Cardinale BJ, Palmer MA, Ives AR, and Brooks SS. 2005. Diversity-productivity relationships in streams vary as a function of the natural disturbance regime. Ecology 86:716-726.

Cederholm CJ, Kunze MD, Murota, T, and Sibatani A. 1999. Pacific salmon carcasses: Essential contributions of nutrients and energy for aquatic and terrestrial ecosystems. Fisheries 24: 6-15

Chaloner DT, Martin KM, Wipfli MS, Ostrom PH, and Lamberti GA. 2002. Marine carbon and nitrogen in southeastern Alaska stream food webs: evidence from artificial and natural streams. Canadian Journal of Fisheries and Aquatic Sciences 56:1257-1265.

Chaloner DT, Lamberti GA, Cak AD, Blair NL, and Edwards RT. 2007. Interannual variation in responses of water chemistry and epilithon to Pacific salmon spawners in an Alaska stream. Freshwater Biology 52:478-490.

Claeson SM, Li JL, Compton JA, and Bisson PA. 2006. Response of nutrients, biofilm and benthic insects to salmon carcass addition. Canadian Journal of Fisheries and Aquatic Sciences 63:1230-1241.

Compton JE, Anderson CP, Phillips DL, Brooks JR, Johnson MG, Church MR, Hogsett, WE, Cairns MA, Rygiewicz PT, McComb BC, and Shaff CD. 2006. Ecological and water quality consequences of nutrient addition for salmon restoration in the Pacific northwest. Frontiers in Ecology and the Environment 4:18-26.

Cooney TJ and Simon KS. 2009. Influence of dissolved organic matter and invertebrates on the function of microbial films in groundwater. Microbial Ecology 58:599-610.

Cram JM, Kiffney PM, Klett R, and Edmonds RL. 2011. Do fall additions of salmon carcasses benefit food webs in experimental streams?. Hydrobiologia 675:197-209. 
Cross WF, Wallace JB, Rosemond AD, and Eggert SL. 2006. Whole-system nutrient enrichment increases secondary production in a detritus-based ecosystem. Ecology $87: 1556-1565$.

D’Angelo DJ, Webster JR, Gregory SV, and Meyer JL. 1993. Transient storage in Appalachian and Cascade mountain streams as related to hydraulic characteristics. Journal of the North American Benthological Society 12:223-235.

Davis JC. 1995. Function processes in three wilderness streams. M.Sc. thesis. Idaho State University. Pocatello, ID.

del Giorgio PA and Cole JJ. 1998. Bacterial growth efficiency in natural aquatic systems. Annual Review of Ecology and Systematics 29:503-541.

Demars BOL, Manson JR, Olafsson JS, Gislason GM, Gudmundsdottir R, Woodward G, Reiss J, Pichler DE, Rasmussen JJ, and Friberg N. 2011. Temperature and the metabolic balance of streams. Freshwater Biology 56:1106-1121.

Evermann BW. 1896. A report on salmon investigations in the headwaters of the Columbia River, in the state of Idaho, in 1896, together with notes upon the fishes observed in that state in 1894 and 1895. Bulletin of the United States Fish Commisson XVI:149-202.

Fellows CS, Valett HM, and Dahm CN. 2001. Whole-stream metabolism in two montane streams: Contribution of the hyporheic zone. Limnology and Oceanography 46:523531.

Fenoglio S, Bo T, Cammarata M, Malacarne G, and Del Frate G. 2010. Contribution of macro- and micro-consumers to the decomposition of fish carcasses in low-order streams: an experimental study. Hydrobiologia 637:219-228.

Fisher SG and Likens GE. 1973. Energy flow in Bear Brook, New Hampshire: An integrative approach to stream ecosystem metabolism. Ecological Monographs 43:421-439.

Gresh T, Lichatowich J, and Schoonmaker P. 2000. An estimation of historic and current levels of salmon production in the northeast Pacific ecosystem. Fisheries 25:15-21.

Griswold RG, Taki D, and Stockner JG. 2003 Redfish lake sockeye salmon: nutrient supplementation as a means of restoration. In: Stockner J. Nutrients in salmonid ecosystems sustaining production and biodiversity. American Fisheries Society Symposium 34:197-211.

Haack SK, Burton T, and Ulrich K. 1988. Effects of whole-tree harvest on epilithic bacterial populations in headwater streams. Microbial Ecology 16:165-181. 
Hall RO, Baker MA, Arp CD, and Koch BJ. 2009. Hydrologic control of nitrogen removal, storage, and export in a mountain stream. Limnology and Oceanography $54: 2128-2142$.

Hall RO and Tank JL. 2005. Correcting whole-stream estimates of metabolism for groundwater input. Limnology and Oceanography: Methods 3:222-229.

Harpole WS, Ngai JT, Cleland EE, Seabloom EW, Borer ET, Bracken MES, Elser JJ, Gruner DS, Hillebrand H, Shurin JB, and Smith JE. 2011. Nutrient co-limitation of primary producer communities. Ecology Letters 14:852-862.

Hart DD and Robinson CT. 1990. Resource limitation in a stream community: Phosphorus enrichment effects on periphyton and grazers. Ecology 71:1494:1502.

Helfield JM and Naiman RJ. 2001. Effects of salmon derived nitrogen on riparian forest growth and implications for stream productivity. Ecology 82:2403-2409.

Hicks BJ, Wipfli MS, Lang DW, and Lang ME. 2005. Marine derived nitrogen and carbon in freshwater-riparian food webs of the Copper River delta, southcentral Alaska. Oecologia 144:558-569.

Hill WR, Roberts BJ, Francoer SN, and Fanta SE. 2011. Resource synergy in stream periphyton communities. Journal of Ecology 99:454-463.

Hill WR, Ryon MG, and Schilling EM. 1995. Light limitation in a stream ecosystem: responses by primary producers and consumers. Ecology 76:1297-1309.

Hillebrand H and Kahlert M. 2001. Effect of grazing and nutrient supply on periphyton biomass and nutrient stoichiometry in habitats of different productivity. Limnology and Oceanography 46:1881-1898.

Holtgrieve GW and Schindler DE. 2011. Marine-derived nutrients, bioturbations and ecosystem metabolism: reconsidering the role of salmon in streams. Ecology 92:373385.

Holtgrieve GW, Schindler DE, Gowell CP, Ruff CP, and Lisi PJ. 2010. Stream geomorphology regulates the effects on periphyton of ecosystem engineering and nutrient enrichment by Pacific salmon. Freshwater Biology 55:2598-2611.

Hornberger GM and Kelly MG. 1975. Atmospheric reaeration in a river using productivity analysis. Journal of the Environmental Engineering Division ASCE 101: 729-739. 
Hyatt KD, McQueen DJ, Shortreed KS, and Rankin DP. 2004. Sockeye salmon (Oncorhynchus nerka) nursery lake fertilization: review and summary of results. Environmental Reviews 12:133-162.

Izagirre O, Bermejo M, Pozo J, and Elosegi A. 2007. RIVERMET@: An Excel-based tool to calculate river metabolism from diel oxygen-concentration curves.

Environmental Modelling and Software 22:24-32.

Janetski DJ, Chaloner DT, Tiegs SD, and Lamberti GA. 2009. Pacific salmon effects on stream ecosystems: a quantitative synthesis. Oecologia 159:583-595.

Juday C, Rich WH, Kemmerer GI, and Mann A. 1932. Limnological studies of Karluk Lake, Alaska 1926-1930. Bulletic of the Bureau of Fisheries 47:407-436.

Kiernan JD, Harvey BN, and Johnson ML. 2010. Direct versus indirect pathways of salmon-derived nutrient incorporation in experiemental lotic food webs. Canadian Journal of Fisheries and Aquatic Sciences 67:1909-1924.

Kiffney PM, Richardson JS, and Bull JP. 2004. Establishing light as a causal mechanism structuring stream communities in response to experimental manipulation of riparian buffer width. Journal of the North American Benthological Society 23:542-555.

Kiffney PM, and Roni P. 2007. Relationships between productivity, physical habitat and aquatic invertebrate and vertebrate populations of forest streams: and information theoretic approach. Transactions of the American Fisheries Society 136:1088-1103.

Kline TC, Goering JJ, Mathisen OA, Poe PH, and Parker PL. 1990. Recycling of elements transported upstream by runs of Pacific salmon: I. $\delta^{15} \mathrm{~N}$ and $\delta^{13} \mathrm{C}$ evidence in Sashin Creek, southeastern Alaska. Canadian Journal of Fisheries and Aquatic Sciences 50:2350-2365.

Kohler AE, Rugenski, and Taki D. 2008. Stream food web response to a salmon carcass analogue addition in two central Idaho, U.S.A. streams. Freshwater Biology 53:446460.

Kohler AE and Taki D. 2010. Macroinvertebrate response to salmon carcass analogue treatments: exploring the relative influence of nutrient enrichment, stream foodweb, and environmental variables. Journal of the North American Benthological Society 29:690-710.

Kohler AE, Pearsons TN, Zendt JS, Mesa MG, Johnson CL, and Connolly PJ. 2012. Nutrient enrichment with salmon carcass analogs in the Columbia River basin, USA: a stream food web analysis. Transactions of the American Fisheries Society 141:802824. 
Kreft J. 2004. Biofilms promote altruism. Microbiology 150:2751-2750.

Lamberti GA and Resh VH. 1983. Stream periphyton and insect herbivores: an experimental study of a grazing caddisfly population. Ecology 64: 1124-1135.

Lamberti GA, Gregory SV, Ashkenas LR, Steinman AD, and McIntire CD. 1989. Productive capacity of periphyton as a determinant of plant-herbivore interactions in streams. Ecology 70:1840-1856.

Larkin GA and Slaney PA. 1997. Implications of trends in marine-derived nutrient influx to south coastal British Columbia salmonid production. Fisheries 22:16-24.

Lennon JT and Jones SE. 2011. Microbial seed banks: the ecological and evolutionary implications of dormancy. Nature Reviews Microbiology 9:119-130.

Lichatowich J. 1999. Salmon Without Rivers: A History of the Pacific Salmon Crisis. Island Press, Washington, D.C., U.S.A.

Logan J and Powell J. 2001. Ghost forests, global warming, and the mountain pine beetle (Coleoptera : Scolytidae). American Entomologist 47:160-173.

Lowe RL, Golladay SW, and Webster JR. 1986. Periphyton response to nutrient manipulation in streams draining clearcut and forested watersheds. Journal of the North American Benthological Society 5:221-229.

Malison RL and Baxter CV. 2010. The fire pulse: wildfire stimulates flux of aquatic prey to terrestrial habitats driving increases in riparian consumers. Canadian Journal of Fisheries and Aquatic Sciences 67:570-579.

Marcarelli AM and Wurtsbaugh WA. 2007. Effects of upstream lakes and nutrient limitation on periphytic biomass and nitrogen fixation in oligotrophic subalpine streams. Freshwater Biology 52:2211-2225.

Marcarelli AM, Baxter CV, Mineua MM, and Hall RO. 2011. Quantity and quality: unifying food web and ecosystem perspectives on the role of resource subsidies in freshwaters. Ecology 92: 1215-1225.

Marzolf ER, Mulholland PJ, and Steinman AD. 1994. Improvements to the diurnal upstream-downstream dissolved oxygen change technique for determining wholestream metabolism in small streams. Canadian Journal of Fisheries and Aquatic Sciences 51:1591-1599.

McIntire CD and HK Phinney. 1965. Laboratory studies of periphyton production and community metabolism in lotic environments. Ecological Monographs 35:237-258. 
Melching CS and Flores HE. 1999. Reaeration equations derived from U.S. Geological Survey database. Journal of Environmental Engineering 125:407-414.

Minshall GW, Hitchcock E, and Barnes JR. 1991. Decomposition of rainbow trout (Oncorhynchus mykiss) carcasses in a forest stream ecosystem inhabited only by nonanadromous fish populations. Canadian Journal of Fisheries and Aquatic Sciences 48:191-195.

Mitchell NL and Lamberti GA. 2005. Responses in dissolved nutrients and epilithon abundance to spawning salmon in southeast Alaska streams. Limnology and Oceanography 50:217-227.

Moore JC, Berlow EL, Coleman DC, de Ruiter PC, Dong Q, Hastings A, Johnson NC, McCann KS, Melville K, Morin PJ, Nadelhoffer K, Rosemond AD, Post, DM, Sabo JL, Scow KM, Vanni MJ, and Wall DH. 2004. Detritus, trophic dynamics and biodiversity. Ecology Letters 7:584-600.

Moore JW and Schindler DE. 2008. Biotic disturbance and benthic community dynamics in salmon-bearing streams. Journal of Animal Ecology 77:275-284.

Moore JW, Schindler DE, Carter JL, Fox J, Griffiths J, and Holtgrieve GW. 2007. Biotic control of stream fluxes: spawning salmon drive nutrient and matter export. Ecology $88: 1278-1291$

Mulholland PJ, Steinman AD, Marzolf ER, Hart DR, and DeAngelis DL. 1994. Effect of periphyton biomass on hydraulic characteristics and nutrient cycling in streams. Oecologia 98:40-47.

Mulholland PJ, Marzolf ER, and Webster JR. 1997. Evidence that hyporheic zones increase heterotrophic metabolism and phosphorus uptake in forest streams. Limnology and Oceanography 42: 443-451.

Mulholland PJ, Fellows CS, Tank JL, Grimm NB, Webster JR, Hamilton SK, Marti E, Ashkenas L, Bowden WB, Dodds WK, McDowell WH, Paul MJ, and Peterson BJ. 2001. Interbiome comparison of factors controlling stream metabolism. Freshwater Biology 46:1503-1517.

Nakano S, Miyasaka H, and Kuhara N. 1999. Terrestrial-aquatic linkages: riparian arthropod inputs alter trophic cascades in a stream food web. Ecology 80:2435-2441.

National Atmospheric Deposition Program (2010) NADP Program Office, Illinois State Water Survey. 2204 Griffith Dr, Champaign, IL. 
Nehlsen W, Williams JE, and Lichatowich JA. 1991. Pacific salmon at the crossroads: stocks at risk from California, Oregon, Idaho, and Washington. Fisheries 16:4-21.

Nelson PR and Edmondson WT. 1955. Limnological effects of fertilizing Bare Lake, Alaska. Fishery Bulletin of the Fish and Wildlife Service. 56:413-436.

ODFW (Oregon Department of Fish and Wildlife). 2009. Fish propagation annual report for 2009. Portland, OR: Oregon Department of Fish and Wildlife

O'Keefe TC and Edwards RT. 2002. Evidence for hyporheic transfer and removal of marine-derived nutrients in a sockeye stream in southwest Alaska. American Fisheries Society Symposium 33:99-107.

Omernik JM. 1987. Ecoregions of the coterminous United States. Annals of the Association of American Geographers 77:118-125.

Pearson TN, Roley DD, and Johnson CL. 2007. Development of a carcass analog for nutrient restoration in streams. Fisheries 32:114-124.

Peterson DP and Foote CJ. 2000. Disturbance of small-stream habitat by spawning sockeye salmon in Alaska. Transactions of the American Fisheries Society 129:924934.

Peterson BJ, Hobbie, JE, Hershey AE, Lock MA, Ford TE, Vestal JR, McKinley VL, Hullar MAJ, Miller MC, Ventullo RM, and Volk GS. 1985. Transformation of a tundra river from heterotrophy to autotrophy by addition of phosphorus. Science 229:1383-1386.

Peterson B, Fry B, and Deegan L. 1993. The trophic significance of epilithic algal production in a fertilized tundra river ecosystem. Limnology and Oceanography 38:872-878.

Pinay G, O'Keefe T, Edwards R, and Naiman RJ. 2003. Potential denitrification activity in the landscape of a western Alaska drainage basin. Ecosystems 6:336-343.

Polis GA, Anderson WB, and Holt RD. 1997. Towards an integration of landscape and food web ecology: the dynamics of spatially subsidized food webs. Annual Review of Ecology Systematics 28:289-316.

Raymond PA, Zappa CJ, Butman D, Bott TL, Potter J, Mulholland P, Laursen AE, McDowell WH, and Newbold D. 2012. Scaling the gas transfer velocity and hydraulic geometry in streams and small rivers. Limnology and Oceanography: Fluids and Environments 2:41-53. 
Rex JF and Petticrew EL. 2008. Delivery of marine-derived nutrients to streambeds by Pacific salmon. Nature Geosciences 1:840-843.

Rex JF and Petticrew EL. 2010. Salmon-derived nitrogen delivery and storage within a gravel bed: sediment and water interactions. Ecological Engineering 36:1167-1173.

Rier ST and Stevenson RJ. 2002. Effects of light, dissolved organic carbon, and inorganic nutrients on the relationship between algae and heterotrophic bacteria in stream periphyton. Hydrobiologia 489:179-184.

Ries KG, Steeves PA, Coles JD, Rea AH, and Stewart DW. 2004. StreamStats: A U.S. Geological Survey web application for stream information. U.S. Geological Survey Fact Sheet 2004-3115, 4 p.

Roberts BJ, Mulholland PJ, and Hill WR. 2007. Multiple scales of temporal variability in ecosystem metabolism rates: Results from 2 years of continuous monitoring in a forested headwater stream. Ecosystems 10:588-606.

Romani AM and Sabater S. 2001. Structure and activity of rock and sand biofilms in a Mediterranean stream. Ecology 82:3232-3245.

Romani AM, Giorgi A, Acuna V, and Sabater S. 2004. The influence of substratum type and nutrient supply on biofilm organic matter utilization in streams. Limnology and Oceanography 49:1713-1721.

Rosemond AD. 1993. Interactions among irradiance, nutrients, and herbivores constrain a stream algal community. Oecologia 94:585-594.

Ruegg J, Tiegs SD, Chaloner DT, Levi PS, Tank JL, and Lamberti GA. 2011. Salmon subsidies alleviate nutrient limitation of benthic biofilms in southeast Alaska streams. Canadian Journal of Fisheries and Aquatic Sciences 68:277-287.

Ruegg J, Chaloner DT, Levi PS, Tank JL, Tiegs SD, and Lamberti GA. 2012. Environmental variability and the ecological effects of spawning Pacific salmon on stream biofilm. Freshwater Biology 57:129-142.

Rugenski AT, Marcarelli AM, Bechtold HA, and Inouye RS. 2008. Effects of temperature and concentration on nutrient release rates from nutrient diffusing substrates. Journal of the North American Benthological Society 27:52-57.

Russell JB. 2007. The energy spilling reactions of bacteria and other organisms. Journal of Molecular Microbiology and Biotechnology 13:1-11.

Sanderson BL, Coe HJ, Tran CD, Macneale KH, Harstad DL, and Goodwin AB. 2009. Nutrient limitation of periphyton in Idaho streams: results from nutrient diffusing 
substrate experiments. Journal of the North American Benthological Society 28:832845.

Schade JD, Fisher SG, Grimm NB, and Seddon JA. 2001. The influence of a riparian shrub on nitrogen cycling in a Sonoran desert stream. Ecology 82:3363-3376.

Schimel J, Balser TC, and Wallenstein M. 2007. Microbial stress-response physiology and its implications for ecosystem function. Ecology 88:1386-1394.

Schindler DE, Hilborn R, Chasco B, Boatright CP, Quinn TP, Rogers LA, and Webster MS. 2010. Populations diversity and the portfolio effect in an exploited species. Nature 465:609-612.

Scott JT, Back JA, Taylor JM, and King RS. 2008. Does nutrient enrichment decouple algal-bacterial production in periphyton. Journal of the North American Benthological Society 27:332-344.

Sobczak WV. 1996. Epilithic bacterial responses to variations in algal biomass and labile dissolved organic carbon during biofilm colonization. Journal of the North American Benthological Society 15:143-154.

Stevenson RJ. 1997. Scale-dependent determinants and consequences of benthic algal heterogeneity. Journal of the North American Benthological Society 16: 248-262.

Stoodley P, Dodds I, Boyle JD, and Lappin-Scott HM. 1999. Influence of hydrodynamics and nutrients on biofilm structure. Journal of Applied Microbiology. 85:19S-28S.

Suberkropp K, Gulis V, Rosemond AD, and Benstead JP. 2010. Ecosystem and physiological scales of microbial responses to nutrients in a detritus-based ecosystem: results of a 5-year continuous enrichment. Limnology and Oceanography 55:149-160.

Tank JL and Dodds WK. 2003. Nutrient limitation of epilithic and epixylic biofilms in ten North American streams. Freshwater Biology 48:1031-1049.

Tank JL, Rosi-Marshall EJ, Griffiths NA, Entrekin SA, and Stephen ML. 2010. A review of allochthonous organic matter dynamics and metabolism in streams. Journal of the North American Benthological Society 29:118-146.

Thomas SA, Royer TV, Minshall GW, and Snyder E. 2003. Assessing the historic contribution of marine-derived nutrients to Idaho streams. American Fisheries Society Symposium 34:41-55.

Tiegs SD, Campbell EY, Levi PS, Ruegg J, Benbow ME, Chaloner DT, Merritt RW, Tank JL and Lamberti GA. 2009. Separating physical disturbance and nutrient 
enrichment caused by Pacific salmon in stream ecosystems. Freshwater Biology 54. 1864-1875.

Tiegs SD, Levi PS, Ruegg J, Chaloner DT, Tank JL, and Lamberti GA. 2011. Ecological effects of live salmon exceed those of carcasses during an annual spawning migration. Ecosystems 14:598-614.

Triska FJ, Kennedy VC, Avanzino RJ, Zellweger GW, and Bencala KE. 1989. Retention and transport of nutrients in a third-order stream: channel processes. Ecology 70:1877-1892.

Tsivoglou EC and Neal LA. 1976. Tracer measurement of reaeration: III. predicting the reaeration capacity of inland streams. Journal of the Water Pollution Control Federation 48:2669-2689.

Uehlinger U. 2006. Annual cycle and inter-annual variability of gross primary production and ecosystem respiration in a flood prone river during a 15 year period. Freshwater Biology 51:938-950.

Valett HM, Thomas SA, Mulholland PJ, Webster JR, Dahm CN, Fellows CS, Crenshaw CL, and Peterson CG. 2008. Endogenous and exogenous control of ecosystem function: N cycling in headwater streams. Ecology 89:3515-3527.

Van Horn DJ, Sinsabaugh RL, Takacs-vesbach CD, Mitchell KR, and Dahm CN. 2011. Response of heterotrophic stream biofilm communities to a gradient of resources. Aquatic Microbial Ecology 64:149-161.

Verspoor JJ, Braun DC, and Reynolds JD. 2010. Quantitative links between Pacific salmon and stream periphyton. Ecosystems 13:1020-1034.

Wallin MB, Oquist MG, Buffam, I, Billett MF, Nisell J, and Bishop KH. 2011. Spatiotemporal variability of the gas transfer coefficient $\left(\mathrm{K}_{\mathrm{CO} 2}\right)$ in boreal streams: implications for large scale estimates of $\mathrm{CO}_{2}$ evasion. Global Biogeochemical Cycles 25: GB3025, 14pp.

Webster JR and Meyer JL. 1997. Organic matter budgets for streams: a synthesis. Journal of the North American Benthological Society 16:141-161.

Wetzel, R.G. and G.E. Likens. 2000. Limnological Analyses. Springer-Verlag New York, Inc., New York, New York, U.S.A.

Wipfli MS and Baxter CV. 2010. Linking ecosystems, food webs, and fish production: subsidies in salmonid watersheds. Fisheries 35:373-387. 
Wipfli MS, Hudson J, and Caoulette J. 1998. Influence of salmon carcasses on stream productivity: response of biofilm and benthic macroinvertebrates in southeastern Alaska, U.S.A. Canadian Journal of Fisheries and Aquatic Sciences 55:1503-1511.

Wipfli MS, Hudson JP, and Caouette JP. 2003. Marine subsidies in freshwater ecosystems: salmon carcasses increase the growth rates of stream-resident salmonids. Transactions of the American Fisheries Society 132:371-381.

Wipfli MS, Hudson JP, and Caouette JP. 2004. Restoring productivity of salmon based food webs: contrasting effects of salmon carcass and salmon carcass analog additions on stream-resident salmonids. Transactions of the American Fisheries Society 133:1440-1454.

Wipfli MS, Hudson JP, Chaloner DT, and Caouette JP. 1999. Influence of spawner densities on stream productivity in southeast Alaska. Canadian Journal of Fisheries and Aquatic Sciences 56:1600-1611.

Wipfli MS, Hudson JP, Caouette JP, Mitchell NL, Lessard JL, Heintz RA, and Chaloner DT. 2010. Salmon carcasses increase stream productivity more than inorganic fertilizer pellets: a test on multiple trophic levels in streamside experimental channels. Transactions of the American Fisheries Society 139:824-839.

Young, R. G., and A. D. Huryn. 1998. Comment: Improve- ments to the diurnal upstream-downstream dissolved ox- ygen change technique for determining wholestream metabolism in small streams. Canadian Journal of Fisheries and Aquatic Sciences 55:1784-1785.

Young RG and Huryn AD. 1999. Effects of land use on stream metabolism and organic matter turnover. Ecological Applications 9:1359-1376.

Ziegler SE and Lyon DR. 2010. Factors regulating epilithic biofilm carbon cycling and release with nutrient enrichment in headwater streams. Hydrobiologia 657:71-88. 